\title{
«Золотой зал» Национального музея Тувы как культурное явление
}

\author{
Шолбана Х. Монгуш, Мерген А. Монгуш \\ Национальный музей им. Алдан-Маадыр Республики Тыва, Российская Федерация
}

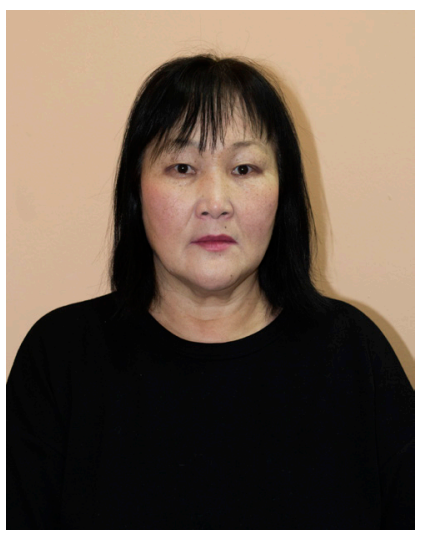

Коллекция археологических находок из иарского кургана Аржан-2 (Тува, Россия) появилась в экспозиции Национального музея им. Алдан-Маадыр Республики Тыва в 2008 г. и сразу образовала центральную выставку музея с названием «Сокровища Долины царей. Царский курган Аржан-2». Она вызвала интерес к скифскому наследию у многочисленных посетителей, что отразилось в культурной жизни республики, а также стала определять и внешние культурные связи Тувы.

В статье показана предыстория создания экспозиции, процесс реэкспозиции выставки. В том числе описаны новые экспонаты 2020 г.: подлинный антропологический материал из статусного погребения погребально-поминального комплекса Аржан-2 (2 половины VII в. до н. э.). Экспозиция пополнена дополнительными деталями парадного костюма. Создана модель могилы №5 кургана Аржан-2 в виде полного комплекта погребально-поминального комплекса. Дана статистика посещаемости музея, начиная с 2008 г., и выставки с сокровищами Долины царей.

Для анализа влияния экспозищии на культурную жизнь Тувы рассмотрены ряд новых изданий, видов продукции, туристических и образовательных проектов, театральных

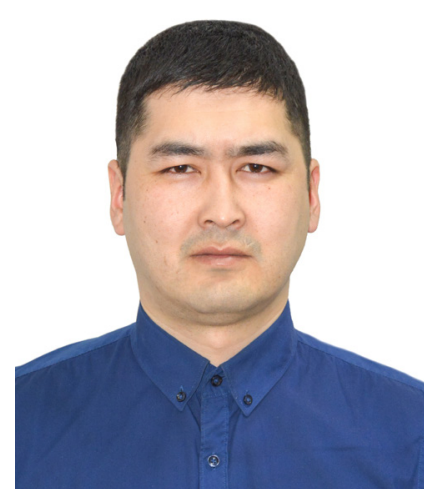
и других культурных событий, которые были созданы с включением скифских мотивов, образов.

Ключевые слова: Тува; Национальный музей Республики Тыва; тувинский музей; долина иарей Тувы; скифы; Аржан-2; экспозиционно-выставочная деятельность; реэкспозиция; музейная коллекция; скифское золото; золотой зал; тувинцы; тувинская культура; туризм Тувы

Для циитирования:

Монгуш Ш. Х., Монгуш М. А. «Золотой зал» Национального музея Тувы как культурное явление // Новые исследования Тувы. 2021, № 1. С. 51-72. DOI: https://www.doi.org/10.25178/nit.2021.1.3

Монгуш Шолбана Хонук-ооловна - старший научный сотрудник отдела археологии Национального музея им. Алдан-Маадыр Республики Тыва. Адрес: 667000, Россия, г. Кызыл, ул. Титова, д. 30. Тел.: +7 (394) 223-06-56. Эл. адрес: sholbana19662017@mail.ru

Монгуш Мерген Александрович - старший научный сотрудник филиала «Алдын дошка» Национального музея им. Алдан-Маадыр Республики Тыва. Адрес: 667000, Россия, г. Кызыл, ул. Титова, д. 30. Тел.: +7(394) 223-06-56. Эл. адрес: monmen1989@mail.ru

MONGUSH, Sholbana Khonuk-oolovna, Senior Research Fellow, Department of Archaeology, Aldan Maadyr National Museum of the Republic of Tuva. Postal address: 30 Titova St., 667000 Kyzyl, Russian Federation. Tel.: +7 (394) 223-06-56. Email: sholbana19662017@mail.ru_ORCID ID:0000-0001-5545-1122 MONGUSH, Mergen Aleksandrovich, Senior Research Fellow, Altyn Doshka branch Aldan Maadyr National Museum of the Republic of Tuva. Postal address: 30 Titova St., 667000 Kyzyl, Russian Federation. Tel.: +7 (394) 223-06-56. Email: monmen1989@ mail.ru ORCID ID: 0000-0003-3667-6910 
Article

\title{
The «Golden Hall» of the National Museum of the Republic of Tuva as a cultural phenomenon
}

\author{
Sholbana Kh. Mongush, Mergen A. Mongush \\ Aldan Maadyr National Museum, Republic of Tuva, Russian Federation
}

\begin{abstract}
The collection of archaeological finds from Arzhan II royal mound (Tuva, Russia) joined the exposition of the Aldan Maadyr National Museum in 2008 and soon became the centerpiece of the museum, permanently exhibited under the title "The treasures of the valley of kings. Royal mound Arzhan II". The exhibition generated a lot of interest in the Scythian heritage among its numerous visitors, which in turn had a profound impact of the cultural life of the region and even on Tuva's cultural relations.

The article examines the background of the exhibition and its subsequent re-displaying and expansion, including the new 2020 exhibits, such as the genuine anthropological material from a high-profile burial on the grounds of Arzhan II complex (latter half of 7th c. BC). The exposition now includes additional accessories of a full dress. A model of Grave, Arzhan II complex, has been created as a full reconstruction of a funeral rite. The article also provides the statistics of museum visits since 2008, and a separate statistics of the Valley of kings exhibition.

The analysis of the impact the exhibition had on Tuva's cultural life covers a number of new books, other produce, touristic and educational events, theatrical and cultural events, all of which make use of Scythian motifs and imagery.
\end{abstract}

Keywords: Tuva; National Museum of the Republic of Tuva; Tuvan museum; valley of Kings in Tuva; Scythians; Arzhan II; exposition work; re-display; museum collection; Scythian gold; Golden Hall; Tuvans; Tuvan culture; tourism in Tuva

\section{Введение}

Республика Тыва имеет уникальное и богатое археологическое наследие. Археологи считают, что здесь «во всех районах можно встретить стоянки древнего человека, поселения эпохи бронзы, средневековые крепости, могильники различных исторических эпох, памятники монументального искусства - оленные камни, тюркские изваяния и рунические стелы, местонахождения наскальных рисунков» (Килуновская, 2012: 102). При этом, по мнению К. В. Чугунова, «подавляющее большинство археологических памятников Тувы составляют древние захоронения - курганы» (Аржан. Источник ..., 2004: 10). В «Долине царей» среди сотен курганов в 1970-1974 гг. исследован раннескифский курган Аржан-1 из-за интенсивного разрушения от внешних факторов. Спустя 30 лет ученые из России и Германии исследовали курган Аржан-2 ${ }^{1}$, он «осыпал археологов подарками и задал великое множество вопросов. Их будет обсуждать не одно поколение исследователей» (Чугунов, Парцингер, Наглер, 2017: 3).

Коллекция кургана Аржан-2 впоследствии экспонировалась: в 2004 г. в Государственном Эрмитаже (г. Санкт-Петербург, Россия) под названием «Аржан. Источник в Долине царей. Археологические открытия в Туве»; в 2007 г. в Музее древней истории (Берлин, Германия), а затем в том же году в гг. Мюнхене и Гамбурге в составе Международной выставки «Под знаком золотого грифона. Царские могилы скифов» (Дыртык-оол, 2009).

${ }^{1}$ Varoli J. Scythian Gold From Siberia Said to Predate the Greeks [Электронный ресурс] // The New York Times. 2002, January 9. URL: https://www.nytimes.com/2002/01/09/arts/scythian-gold-from-siberia-said-to-predate-the-greeks. html (дата обращения: 10.12.2020). 
2 ноября 2008 г. выставка «Сокровища Долины царей. Царский курган Аржан-2» открылась в Национальном музее им. Алдан-Маадыр Республики Тыва (далее - НМ РТ) и с тех пор стала центральной и самой притягательной экспозицией музея. Ее открытие широко освещалось местными, российскими и зарубежными средствами массовой информации (Кудажи, Опей-оол, 2009: 67). Выставку посещают все высокопоставленные гости республики. Более того, выставка вызывает постоянный интерес и творческой интеллигенции республики, которая стала черпать в образах прошлого новые источники для создания своих творений. Тем самым археологические находки древности, экспонируемые в музее, оказывают влияние на современную культурную жизнь Тувы.

И данная статья посвящена анализу этого влияния, что до сих пор не становилось предметом научных исследований.

Следует отметить, что о самом «Золотом зале», как нередко называют эту выставку, написано немало научных работ, которые также стали одним из важных видов источников при подготовке данной статьи: О. О. Монгуш (Монгуш, 2006), Р. Б. Ховалыг (Ховалыг, 2009); А. О. Дыртык-оол (Дыртык-оол, 2009, 2013); К. В. Чугунов, Г. Парцингер, А. Наглер (Чугунов, 2004, 2008ab, 2010; Чугунов, Парцингер, Наглер, 2017); У. Б. Нурзат (Нурзат, 2013); В. А. Семенов, М. Е. Килуновская, О. О. Монгуш (Семенов, Килуновская, Монгуш, 2014). Другими видами источников для анализа стали: публикации в СМИ (2008-2014 гг.) ${ }^{1}$; архивные материалы и документация в фондах НМ РТ; отзывы посетителей НМ РТ; материалы авторских опросов посетителей выставки (2019-2020 гг.).

\section{История создания выставки в тувинском музее}

Данная выставка была создана по решению научно-методического совета музея в 2008 г. Членами творческой рабочей группы были заведующая отделом истории Ш. М. Ондар, главный художник В. Н. Елизаров, художник-оформитель Х. О. Ооржак, художник-оформитель, проходивший государственную практику, А. Т. Ооржак, старший научный сотрудник отдела истории Л. М. Салчак, заведующая образовательно-культурным отделом О. О. Монгуш, старший научный сотрудник отдела истории Ч. А.-С. Монгуш, старший научный сотрудник отдела истории А. В. Ховалыг, ответственный хранитель фонда «Драгметаллы» С. Л. Бырыннай, заведующая отдел природы Л. К. Монгуш, старший научный сотрудник К.-К. Ш. Монгуш, младший научный сотрудник В. Ч. Донгак, художник-оформитель К. А. Донгак, студенты художественного отделения колледжа искусств, электрик музея М. Ш. Яндараа и др. Их всех можно считать авторами экспозиции так, как каждый из них внёс свою определённую лепту в общее дело. Отметим, также вклад студентов Кызылского колледжа искусств им. А. Б. Чыргал-оола, которые помогали от начала до завершения работ. В экспозиции выставлены более четырёх тысяч экспонатов из курганов Аржан-1 и Аржан-2.

Оформление выставки заняло около полтора месяца. Руководство музея проделало большую работу. Были заказаны и установлено оборудование (бронированные витрины), установлены световой и температурно-влажностные режимы, а также охранная сигнализация.

\footnotetext{
${ }^{1}$ Монгуш К. Төөгүлүг зал [Нац. музейде “Аржаан-2” базырыындан тывылган эт-херекселдерни делгеп салыр чаазалдың дугайында] // Шын. 2008, № 127 (17615). С. 2; Кара-оол, Ш. Чуртунче эглип келириниң узун оруу [Скиф уезиниң эртинелери - төрээн тывазында] // Шын. 2008, Тускай үндүрүлге С. 1; Хоюр-оол Л. Бөмбүрзекте төлептиг черни ээлээн. Сайыт-биле интервью. [Скиф уезиниң эртинелери - төрээн тывазында] // Шын. 2008, Тускай үндүрүлге С. 2; Монгуш К. Төөгүлүг, үнелиг зал [Скиф уезиниң эртинелери - төрээн тывазында] // Шын. 2008, Тускай үндүрүлге. С. 3; Аркчаа К. Д. (Даржан А. очулдурган) Тываның скифтериниң дугайында [Скиф уезиниң эртинелери - төрээн тывазында] // Шын. 2008, Тускай үндүрүлге. С. 4-5; Аракчаa К. Д. О скифах Тувы: [к открытию экспозиции Аржаан-2 в Нац. музее им. Алдан-Маадыр] // Тувинская правда. 2008, № 135 (16643). С. 4; Шагжина Н. Особые условия для царских предметов: [Золото скифов: долгий путь домой] // Тувинская правда. 2008, № 135 (16643). С. 3. Аракчаа К. О скифах Тувы: [Золото скифов: долгий путь домой] // Тувинская правда. 2008, № 135 (16643). С. 4-6; Кенин-Лопсан М. Секретная операция [Золото скифов: долгий путь домой] // Тувинская правда. 2008, № 135 (16643). С. 8; Кривдик В. В Долине царей [Золото скифов: долгий путь домой] // Тувинская правда. 2008, №135 (16643). С. 7; Шангина Н. Стерегущие золото грифы... Открытие их тайны сенсация и судьбы: [о выставке «Сокровища Долины царей Тувы». Царский курган «Аржаан-2»] // Тувинская правда. 2009, № 90 (16769). С. 12; Шангина Н. Три фотосессии с золотых скифов // Тувинская правда. 2009, № 90 (16769). С. 12; Дыртык-оол А. О. Сокровища Долины царей Тувы. Царский курган Аржаан-2 // Культура. Искусство Тувы. 2011, Апр. 33. С. 38-41; Качан И. Скифы и чиновники: кто кого? // Плюс Информ. 2014, № 04 (627). С. 8; Чадамба Е. Кто решит судьбу останков скифских властителей: [о круглом столе, посвящ. судьбе останков царской четы из кургана Аржаан-2 в Нац. музее РТ] // Тувинская правда. 2014, № 5 (17464). С. 3.
} 


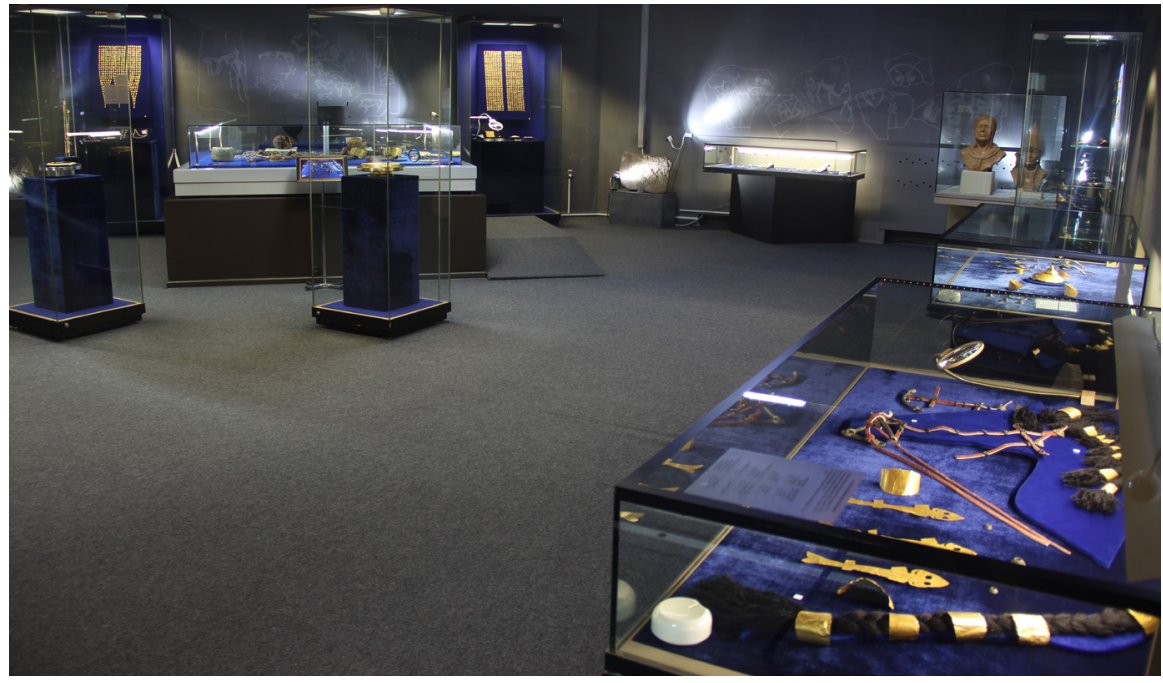

Фото 1. Экспозиционный зал № 4 (Золотой зал) Национального музея Республики Тыва. Фото А. Э. Мижит, 2020 г.

Photo 1. Exhibition Room 4 (The Golden Hall), National Museum of the Republic of Tuva. Photo by A. E. Mizhit, 2020.

Сама выставка состоит из двух экспозиционных залов (№ 3 и № 4, фото 1), где в первом рассказывается история исследования курганов Аржан-1 и Аржан-2, в том числе представляются страницы истории археологических исследований Тувы от древнекаменного века до позднего средневековья. Посетителей встречает на метровом подиуме копия макета кургана Аржан-1, выполненная художниками В. Н. Елизаровым и П. С. Изендеевым в 1997 г. для выставки в старом здании музея. На настенных планшетах дана информация о месторасположении Тувы в

Евразийском материке. Из публикаций учёных-археологов М. П. Грязнова и М. Х. Маннай-оола (Грязнов, Маннай-оол, 1975) показаны разрез, схематический план и основные находки. В стеклянной витрине находится гроб-колода, вырезанная из лиственницы, где по бокам на невысоких подиумах расположены бревна с «проушинами» для перетаскивания.

В остальных витринах и в центральной шестигранной витрине представлены разновременные предметы вооружения воинов, украшения одежды и бытовой посуды. Акцент сделан на деятельности археолога Вл. А. Семенова - руководителя Тувинской археологической экспедиции (с 1984 по настоящее время). Учёный исследует памятники древности на территории Тувы более сорока лет, обогащая фонды археологии НМ РТ.

На южной стороне зала располагается рисунок на настенном макете, художника НМ РТ А. Т. Ооржака - панорама Турано-Уюкской котловины с удивительно красивым ландшафтом. Рядом с копией рядового кургана представлены оригинальные оленные камни и скальные плиты с петроглифами.

Основным экспонатом, передающим информацию об обряде трупоположения, является уменьшенная копия погребальной камеры царя и царицы, по которому можно узнать ещё и приблизительное расположение вещей (фото 2). Наряду с погребением вождей важны и сопутствующие захоронения в кургане. В отдельной витрине показаны предметы, сопутствующие воину. Шейное украшение в форме полумесяца из олова, наконечники из кости и бронзы, а также так называемый скифский набор, состоящий из ножа с ажурной рукоятью, оселка - точильного камня и зеркала. Наконец, для наиболее эффективного раскрытия раздела об исследовании Аржан-2 использованы фотопланшеты, где имеются кадры процесса раскопок, схематического плана объектов, «аржанской» цепи курганов и участников от рядовых копателей, корреспондентов СМИ, специалистов разных отраслей до учёных-археологов - К. В. Чугунова, Г. Парцингера и А. Наглера.

В коридорной части выставки на стенах до входа в бронированный зал золота представлена научная реконструкция одежды царя и царицы, а также основных презентабельных предметов парадного одеяния и вооружения (фото 3).

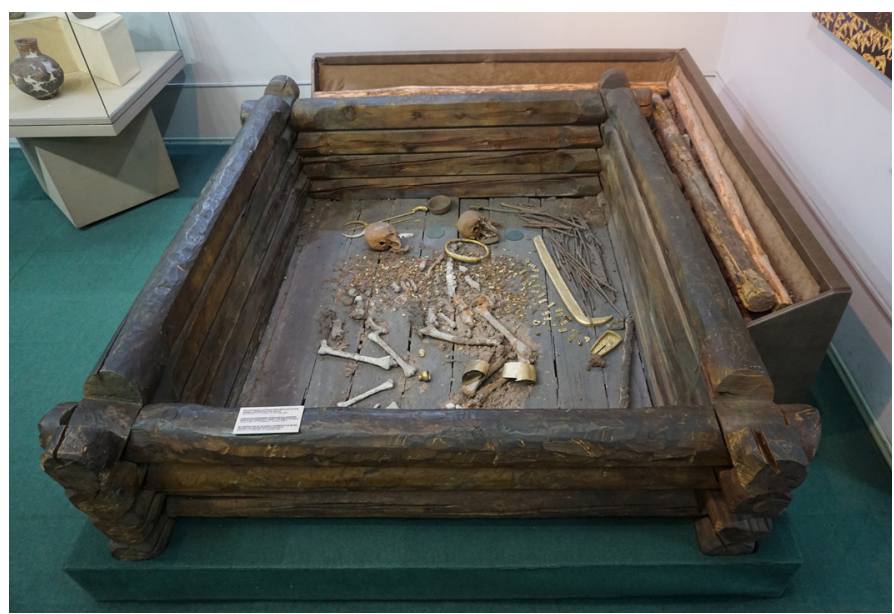

Фото 2. Репродукция могилы 5 кургана Аржан-2 в экспозиции № 3 Национального музея Республики Тыва. Фото М. А. Монгуш, 20202. Photo 2. A reproduction of grave 5 in Arzhan II mound, exposition No. 3, National Museum of the Republic of Tuva. Photo by M. A. Mongush, 2020. 


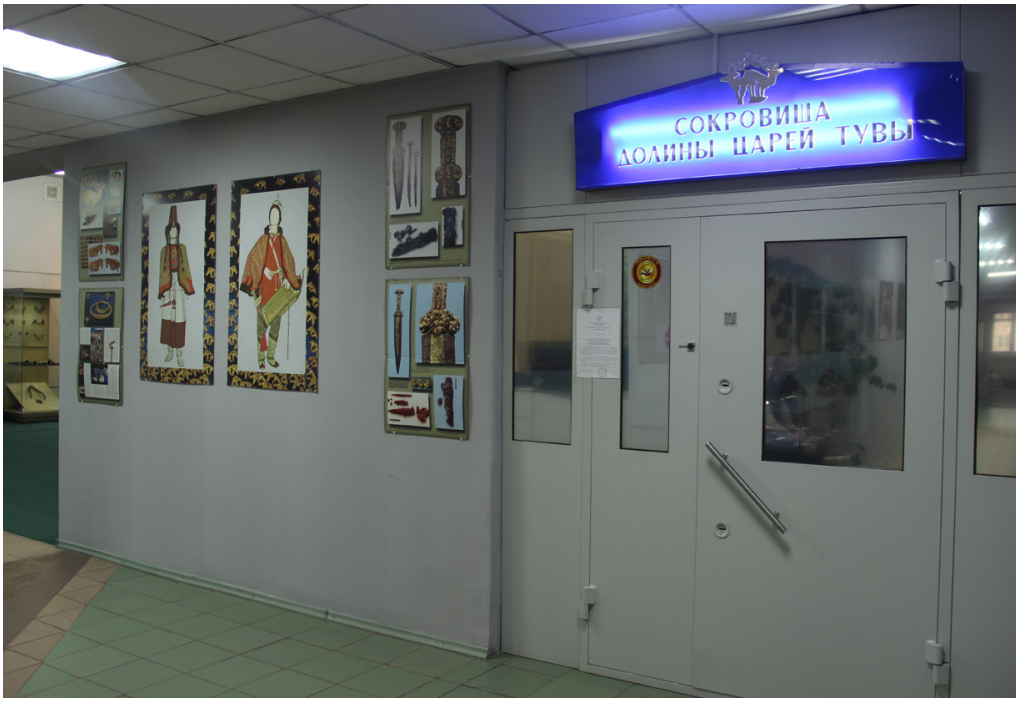

Фото 3. Коридорная часть выставки в Национальном музее Республики Тыва. Фото А. Э. Мижит, 2020 г.

Photo 3. Corridor at the exhibition, National Museum of the Republic of Tuva. Photo by A. E. Mizhit, 2020.

К основной экспозиции «Золотого зала» в 2016 г. прибавилось оформление ещё одной куб-витрины с научной реконструкцией внешнего облика «царских» особ из кургана Аржан-2 по методу М. М. Герасимова. Это реконструкция внешнего облика царя, царицы и одной из приближенных женщин царя, а также палеонтологический материал из кургана Аржан-2 - череп молодой женщины.

В 2019 г. к разделам экспозиции зала украшения одежды царя и царицы в витринах, дополнительно к нашитым на стенд золотым бляшкам, которые украшали поверхность парадной одежды царя и царицы, были добавлены по 42 золотых бляшек к каждой вертикальной витрине в свободно разложенном виде, также золотые бляшки кошачьих хищников ${ }^{1}$.

Экспозиция дополнена предметами конской упряжи. Это золотые пластины из фольги для украшения гривы и хвоста коня, бронзовые псалии ${ }^{2}$, бляшки и ворворки ${ }^{3}$ для уздечки и повода коня. Здесь авторы экспозиции наглядно показали расположение предметов конской упряжи на макете головы, гривны и хвоста коня для того, чтобы познакомить посетителей с конской упряжью. Эта детализация привела к еще большему интересу и к более точному представлению упряжи и украшений коня (фото 4).

Небольшое помещение перед входом в зал золота (предзал) тоже имеет соответствующее оформление (фото 5): на стенах развешаны планшеты с фотографиями находок из курганов Аржан-1 и Аржан-2 известного фотографа Андрея Бронникова, которые используются для передвижных выставок (в районы республики и соседние регионы). На этих фотографиях посетители могут увидеть золотые предметы в увеличенном виде. В витрине представлены золотые находки из «рядовых» погребений

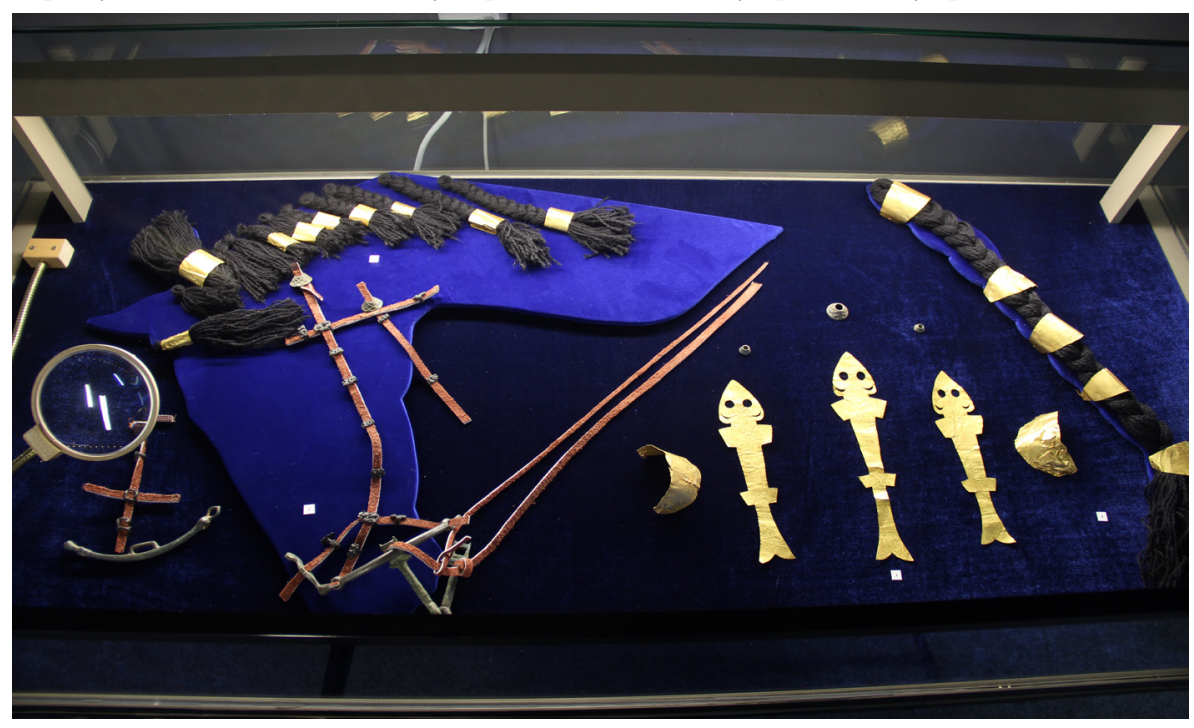

Фото 4. Экспозиционный зал № 4 «Украшения парадного снаряжения коня» Национального музея Республики Тыва. Фото А. Э. Мижит, 2020 г. Photo 4. Exhibition Room 4 "Decoration of the ceremonial horse harness", National Museum of the Republic of Tuva. Photo by A. E. Mizhit, 2020.

${ }^{1}$ Поскольку от посетителей часто поступали вопросы по поводу подлинности золотой коллекции, то все бляшки имеют номерки по книге поступления музея.

${ }^{2}$ Псалии - это конструктивные части узды в виде приспособлений разной конфигурации, представляющие единый механизм с удилами.

${ }^{3}$ Предмет конского снаряжения. 


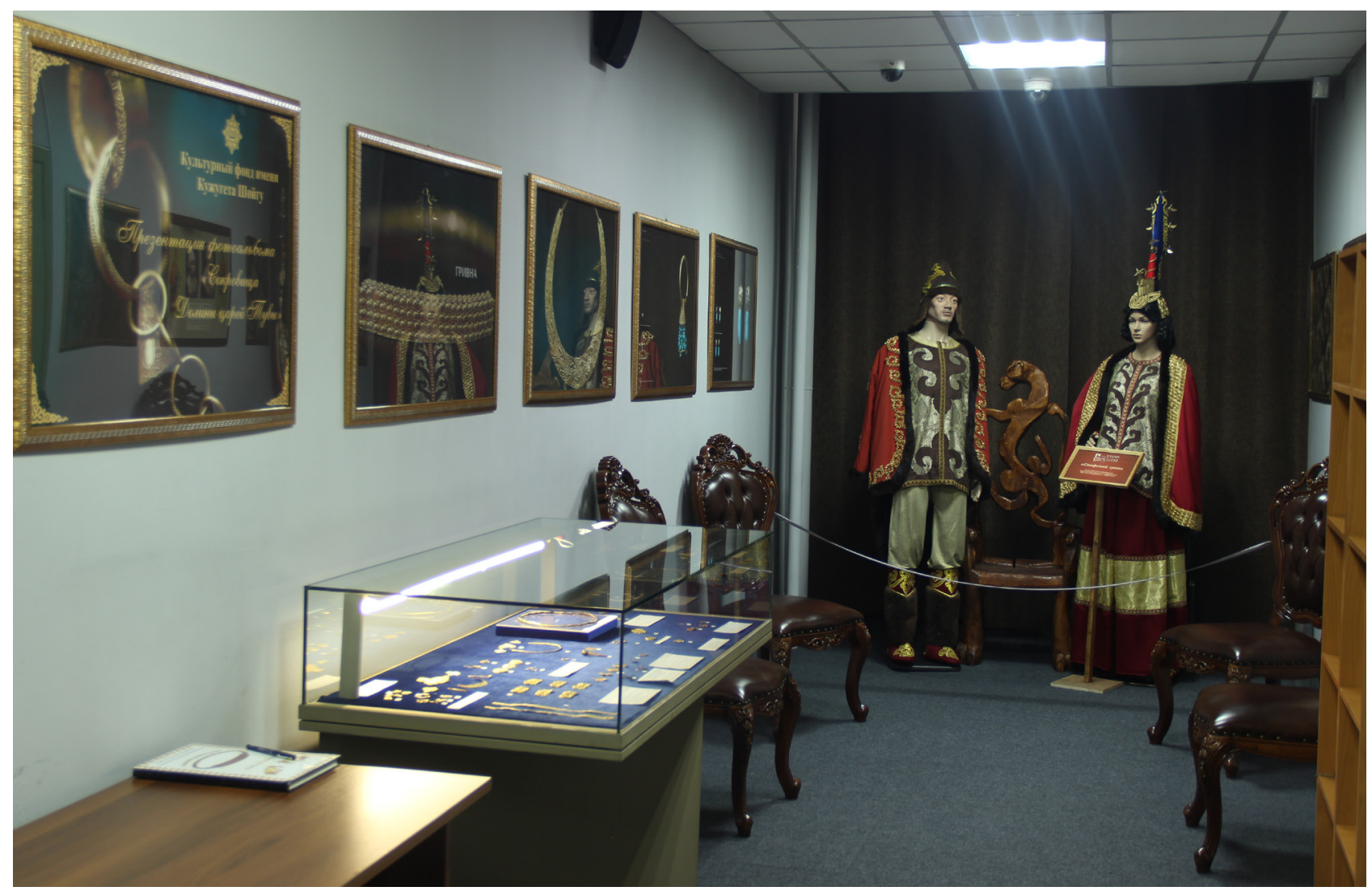

Фото 5. Предзал экспозиционного зала № 4 Национального музея Республики Тыва. Фото А. Э. Мижит, 2020 г.

Photo 5. The ante-room of Exhibition Room 4, National Museum of the Republic of Tuva. Photo by A. E. Mizhit, 2020.

в Кызылском, Пий-Хемском, Барун-Хемчикском и др. районах, чтобы экскурсоводы могли провести параллели в сравнительном анализе со статусными погребениями.

В южной стороне предзала установлены манекены скифского царя и царицы парадном одеянии. Автор костюмов - В. О. Донгак, Заслуженный деятель искусств Республики Тыва. После закупки костюмов, смоделированных В. О. Донгаком, были заказаны копии золотых украшений (бляшки виде кошачьих хищников) из кургана Аржан-2. Их изготовил известный в Туве мастер С. Х. Кочаа, а пришиты к верхней одежде царя и царицы они были мастером Р. А. Донгаком. Эпикировка манекенов состоит из нескольких элементов: головные уборы, норковые накидки (короткий плащ), штаны (у царя), платье (у царицы), сапоги.

Приведем два примера описания (из научного паспорта музейного экспоната) фондовых материалов.

Одеяние царя. Из описания, составленного старшим научным сотрудником отдела археологии НМ РT Ш. Х. Монгуш, следует: «Головной убор царя из кожзаменителя коричневого цвета. По всему краю обшит мехом норки коричневого цвета (шириной 3 см), также полоской из золотистой и зелёной ткани. Украшен с задней стороны металлическими круглыми колокольчиками (7 ед.), сверху с двух сторон вышиты олени из жёлтой парчи» ${ }^{1}$

Одеяние царицы. Из описания: «Головной убор царицы с париком из нескольких косичек чёрного цвета. Украшена золотыми украшениями в виде зажимов на косичках, на макушке головы в виде бус и горного барана, а на верхушке по краям вставки из синего бархата пришиты птички золотистого цвета и олень» ${ }^{2}$.

${ }^{1}$ Составитель паспорта предмета - старший научный сотрудник отдела археологии Ш. Х. Монгуш. Карточка научного описания головного убора царя (научно-вспомогательный фонд-2021/1) (Документация фонда этнографии «Ткань, кожа» НМ РТ).

${ }^{2}$ Составитель паспорта предмета - старший научный сотрудник отдела археологии Ш. Х. Монгуш. Карточка научного описания головного убора царицы (научно-вспомогательный фонд-2021/2) (Документация фонда этнографии «Ткань, кожа» НМ РТ). 
Таким образом, к основной экспозиции золотого зала 2008 г. делались дополнения, производились следующие этапы оформления. Решались задачи достижения полной и детальной презентации статусного погребения кургана Аржан-2. Авторы экспозиции стремились показать подлинные золотые предметы, оформить грамотно этикетаж, установить соответствующее освещение и военизированную охрану по всем требованиям инструкции по учёту и хранению музейных ценностей. Все это было выполнено.

\section{Усыпальница скифского цзаря и царицы}

Реэкспозиция - это обновление содержания части или всей существующей экспозиции, которое регулярно должно производиться в музейной работе.

В январе 2020 г. по инициативе директора НМ РТ К. А. Бичелдея была сформирована рабочая группа музея по созданию первой в истории музея экспозиции усыпальницы царя и царицы в «Золотом зале». Главным для рабочей группы был творческий подход к реэкспозиции. Также было решено, что без антропологического материала выставка не может быть полной.

Возглавил рабочую группу главный хранитель музея Р. Б. Ховалыг. В состав группы вошли: специалисты отдела археологии Ч. А.-С. Монгуш, заведующая отделом археологии, М. А. Монгуш, заведующий филиалом историко-культурного музея-заповедника «Долина царей», Ш. Х. Монгуш, старший научный сотрудник отдела археологии, Ч. М. Топча, младший научный сотрудник отдела археологии, К. М. Монгуш, старший научный сотрудник отдела археологии; а также ответственные хранители отдела фондов: С. Л. Бырыннай, хранитель первой категории фонда драгметалла, С. В. Сат, хранитель первой категории фонда археологии. Группу дополнили специалисты оформительского отдела и рабочие музея: А. Т. Ооржак, художник-оформитель, Э. Б. Ойдуп, специалист оформительского отдела, А. В. Монгуш, столяр, А. А. Дувендей, электрик С. Хертек и др. сотрудники музея.

Для экспонирования ценных предметов необходима специальная витрина. Поэтому в октябре 2019 г. был составлен договор о доставке и установке бронированной витрины размером $300 \times 300$ см с фирмой ООО «Флеш М» г. Красноярска, для экспозиции антропологического материала скифского царя и царицы в «Зале золота». Рабочая группа впервые установила вентиляционную систему поддержки оптимальной температуры внутри витрины. По углам витрины квадратной формы снизу на «полике ${ }^{1 »}$ в заранее приготовленные разъёмы установлены четыре алюминиевых радиатора с вентилятором. Внутри витрины установлены надёжные светодиодные ленты. Пол витрины обтянут бархатной тканью синего света. Проведена адаптация выставочного зала для маломобильных групп населения и инвалидов - создан деревянный пандус для заезда колясок. Для устойчивости конструкция обита мягким напольным покрытием - ковролином.

Место для витрины усыпальницы в зале выбрано на самом почётном месте (дорунде $)^{2}$. По обычаям тувинцев таковое находится на противоположной от двери часть юрты, а в данном случае - на центральной противоположной от двери части выставочного зала. Кроме того, в знак почитания останкам великих предков, витрину возвысили - она помещена на подиум, чуть выше других вертикальных витрин в зале ${ }^{3}$ Установлен соответствующий световой и вентиляционная режимы для поддержки оптимальной температуры в витрине.

Для экспозиции усыпальницы было важно создать модель могилы № 5 кургана Аржан-2 с точным расположением археологических и антропологических материалов. Из фондов археологии НМ РТ получены 2 (мужской и женский скелеты) палеонтологического материала, 3 единиц каменных курильниц из фонда археологии, 452 единиц предметов из фонда драгметаллы. Это 450 единиц $30-$ лотых бляшек в виде кошачьих хищников для верхней одежды погребённых, бронзовое зеркало с 15-ю золотыми обоймами и 1 единица - 40,2 гр. золотого бисера от штанов царя. Для оформления усыпальницы взяты некоторые предметы из уже оформленных витрин общей экспозиции «Золотого зала»: украшения головного убора, одежда и вооружение. Всего их набралось 1113 единиц, это: бирюзовые бусы, накладки для обуви, золотой миниатюрный модель котла, бронзовые зеркала

\footnotetext{
${ }^{1}$ Место расположения экспонатов в витрине.

${ }^{2}$ Почётное место в юрте напротив входа (Толковый словарь ..., 2003: 497).

${ }^{3}$ В создании экспозиции принимали участие представители фирмы ООО «Флеш М» (г. Красноярск). Хотим также отметить трудоёмкую техническую часть работы экспозиции, которую выполнили специалисты оформительского отдела и рабочие музея.
} 
мужской и женской скелетов, горит ${ }^{1}$, пламевидное украшения горита из золотой фольги, портупейный пояс горита, наконечники стрел, бляшки разного размера виде кабанчиков и т. д.

Специалисты отдела археологии (М. А. Монгуш, К. М. Монгуш) выполнили точную раскладку палеонтологических материалов по схеме плана могилы № 5 кургана Аржан-2, ориентируясь на исследование К. В. Чугунова, Г. Парцингера и А. Наглера (Чугунов, Парцингер, Наглер, 2017: 32, 34), в котором говорится, что:

«В середине камеры лежали скелеты двух погребённых головами на северо-запад. Вполне вероятно, что первоначально головы лежали на подушках из органического материала, после разложения которого черепа откатились в сторону. Погребённые лежали на левом боку в слегка скорченном состоянии, ноги были согнуты»; «Скелет 1, лежащий к северо-востоку от середины сруба, принадлежал мужчине 40-45 (50) лет»; «За ним, к юго-западу, лежал скелет 2, принадлежавшей женщине 30-35 лет» (там же).

По расположению костных останков учтены рекомендации Ю. О. Капинус, научного сотрудника Волго-Уральского центра палеоантропологических исследований Самарского государственного социально-педагогического университета г. Самары.

Учитывая предположение исследователей, при раскладке палеонтологических материалов, черепа положили на войлочные подушки, с вышитыми изображениями петроглифов. Также около них с правой стороны разложены бронзовые зеркала с золотыми обоймами на кожаном ремешке. Основные украшения верхней одежды мужского скелета -250 единиц золотых бляшек в виде кошачьих хищников. С правой стороны разложены 100 единиц и с левой 150 единиц, повёрнутых вправо. Также разложены бляшки от верхней одежды женского скелета, всего 200 единиц, повёрнутых влево. Разложенные бляшки, в общем, по нижней части составляют своеобразный узор в виде «пламевидного орнамента» (там же: 61).

С правой стороны мужского скелета положили одно из основных оружий воина - горит с золотой обкладкой (длина 70 см, ширина 5,6 см) и золотой придонной частью предмета каплевидной формы $(17,5 \times 10$ см), пряжку в виде головы птиц $(3,8 \times 4,5$ см), портупейные обоймы $(3,3 \times 1,3$ см) и бляшками в виде фигуры кабанов $(1,2 \times 2,1$ см; $1,6 \times 2,4$ см; всего 163 единиц). А также в той же части располагаются украшение лука из золотой фольги (10×3 cм), полоски - окантовки из проволоки (2-7 см), железные наконечники стрел (от 1 до 10 см; всего 10 единиц) и золотые бисеринки, которые были ранее нашиты на штанах царя (диаметром по 0,1 мм). На уровне ног мужского скелета разложены золотые накладки обуви $\left(13 \times 8\right.$ см). Между двумя скелетами положена золотая миниатюрная модель котла с цепочкой ${ }^{2}$ (диаметр - 3,9 см; длина цепочки - 2 см).

С левой стороны в области шеи второго скелета разложены украшения царицы: бирюзовые бусы (диаметром 0,3-0,5 мм), на стопах многочисленные золотые бусы, которыми была расшита обувь и которые украшали ее золотые пластины (Чугунов, Парцингер, Наглер, 2017: 65) (27×1,1 см). Также к экспозиции усыпальницы добавили каменные курильницы, наполненные можжевельником. Большая каменная курильница с ручкой $(23,5 \times 15,5 \times 10,7$ см) размещена в левом переднем углу витрины, две маленькие - в правом заднем углу.

Таким образом, витрина усыпальницы оформлена с помощью подлинных костных останков скифского царя и царицы из кургана Аржан-2, датируемых 2-й половиной 7 в. до н. э., и содержит 1113 единиц экспонатов из экспозиции зала золота и 457 единиц дополнительных музейных предметов из фонда драгметаллы и археология. Всего перед посетителями в зале 1570 единиц (фото 6).

На западной стороне витрины усыпальницы, на подиуме высотой 1 метр, выставлены 2 бронзовых котла из могилы № 5 Аржан-2. Большой котёл (диаметр устья - 32,8 см, поддона $-13,4$ см, высота 45,6 cм) имеет округлое вытянутое тулово с овальным устьем и утолщённым венчиком. Второй, меньший по размеру котёл (диаметр устья $-22,7$ см, диаметр полого поддона $-13,2$ см, высота $-29,7$ см) имеет округлое и слегка сужающееся к верху тулово, овальное устье и утолщённый венчик (там же: 70).

Экспозиция усыпальницы получилась необычной и интересной. Соответственно, выставка выполнена и представлена перед посетителями музея как полный комплект погребально-поминального комплекса Аржан-2. При этом важным моментом экспозиции было подчеркивание отношения к

${ }^{1}$ Футляр для лука и стрел.

${ }^{2}$ Barbara Armbruster (2009) Gold technology of the ancient Scythians - gold from the kurgan Arzhan 2, Tuva p. 187-193

[Электронный ресурс] // Archeosciences. URL: https://doi.org/10.4000/archeosciences.2193 (дата обращения: 21.01.2020). 


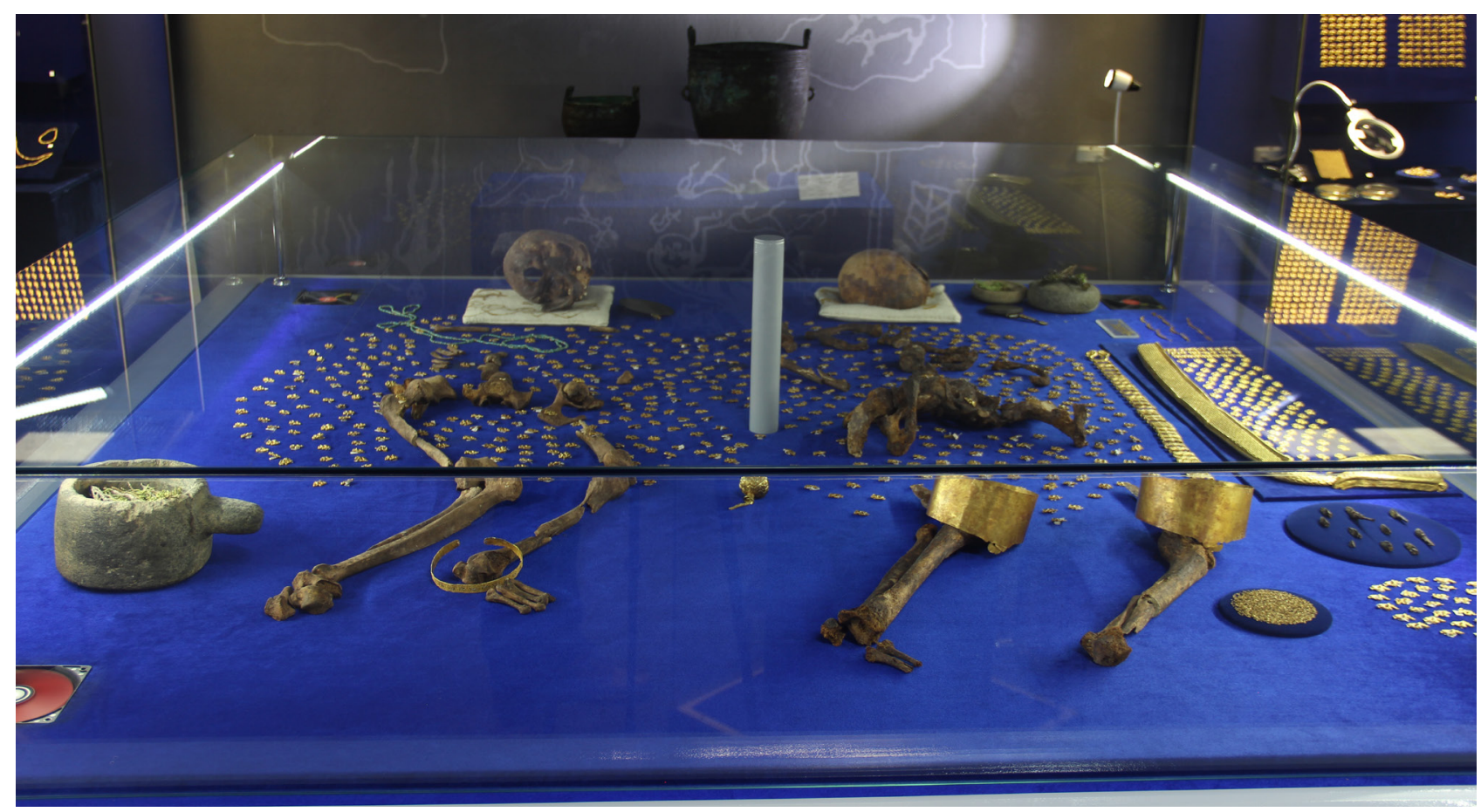

Фото 6. Костные останки скифского царя и царицы в витрине вместе с украшениями и дополнительными предметами. Фото А. Э. Мижит, 2020 г.

Photo 6. Bone remains of a Scythian king and queen in a showcase, with ornaments and additional accessories.

Photo by A. E. Mizhit, 2020.

предкам. Все выстроено таким образом, чтобы посетители видели и понимали все, как знаки почитания и уважения. Тем самым музей демонстрирует этическое отношение к сакральным предметам (Пименова, 2019). Более того, перед открытием усыпальницы в стенах музея был проведен особый обряд камлания верховным шаманом Республики Тыва Кара-оолом Тюлюшовичем Допчун-оолом.

\section{Посещаемость музея и выставки}

Экскурсия традиционно является одной из основных форм культурно-образовательной деятельности музея и статистика этого вида деятельности может показывать востребованность экспозиций, интерес посетителей.

Поэтому представим статистику посещения населением и гостями Республики Тыва музея и выставки «Сокровища Долины царей. Царский курган Аржан-2», учет которой ведется в музее ${ }^{1}$ :

- в 2008 г. проведено 1231 экскурсий, посещаемость 337300 человек;

- в 2009 г. проведено 1768 экскурсий, посещаемость 247000 человек;

- в 2010 г. проведено 1925 экскурсий, посещаемость 36643 человек;

- в 2011 г. проведено 1971 экскурсий, из них Аржан-2 - 1335 экскурсий, посещаемость 44477 человек;

- в 2012 г. проведено 1904 экскурсий, из них по Аржан-2 - 1356 экскурсий, посещаемость 47503 человек;

- в 2013 г. проведено 1870 экскурсий, из них по Аржан-2 - 1341 экскурсий, посещаемость 43368 человек;

- в 2014 г. проведено 2397 экскурсий, из них по Аржан-2 - 1374 экскурсий, посещаемость 48379 человек;

- в 2015 г. проведено 2209 экскурсий, из них по Аржану-2 - 1185 экскурсий, посещаемость 43361 человек;

${ }^{1}$ В 2008-2010, 2016, 2017 гг. подсчёта посетителей выставки Аржан-2 не проводилось. 
- в 2016 г. проведено 2356 экскурсий, посещаемость 40366 человек;

- в 2017 г. проведено 2757 экскурсий, посещаемость 54138 человек;

- в 2018 г. проведено 2175 экскурсий, из них по Аржану-2 - 1490 экскурсий, посещаемость 43964 человек;

- в 2019 г. проведено 2676 экскурсий, из них по Аржану-2 - 1525 экскурсий, посещаемость 44736 человек;

- за 9 месяцев 2020 г. проведено 741 экскурсий, из них по Аржану-2 - 505 экскурсий, посещаемость 15128 человек.

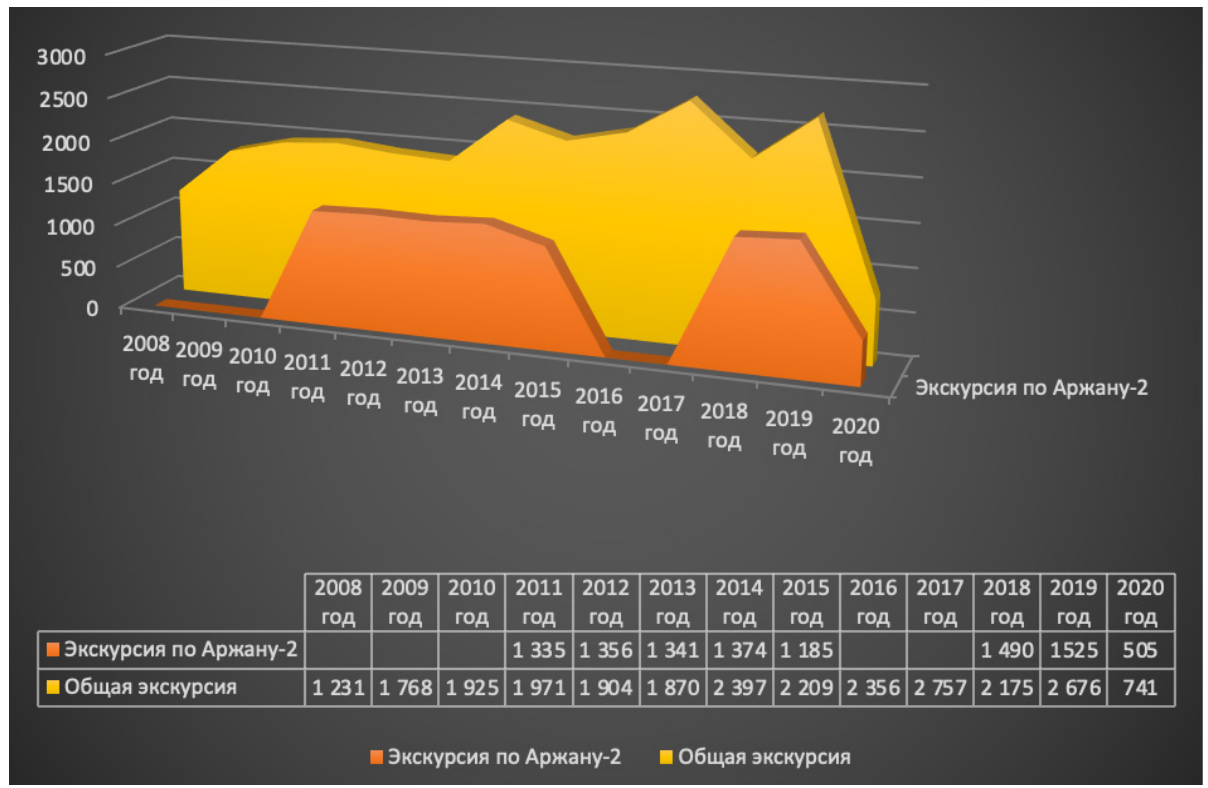

Диаграмма № 1. Экскурсионная деятельность Национального музея Республики Тыва с 2008 по 2020 г2. Diagram 1. Tours given at the National Museum of the Republic of Tuva, 2008-2020.

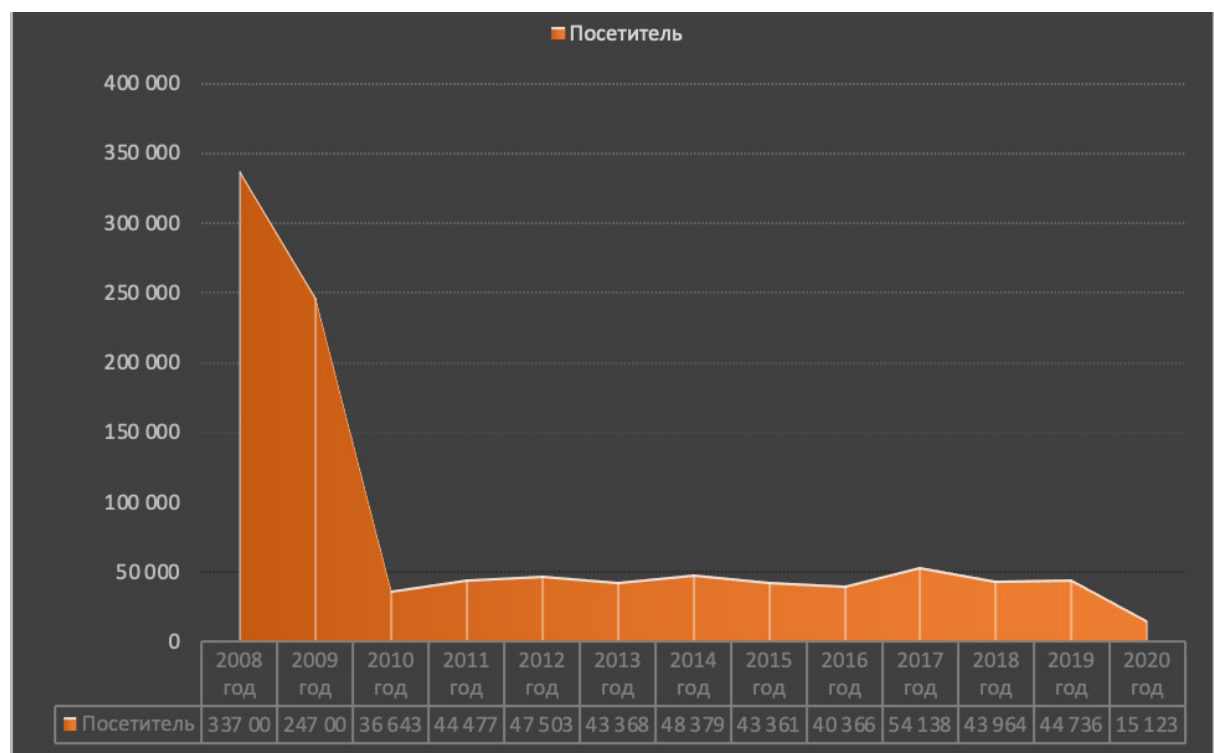

Диаграмма №2. Посещаемость Национального музея Республики Тыва с 2008 по 2020 г2. Diagram 2. The number of visitors at the, National Museum of the Republic of Tuva, 2008-2020.

Данные за 2008 и 2009 гг. показывают нам всплеск увеличения количества посетителей, что было напрямую связано с открытием нового здания музея, с обновлёнными экспозициями о Туве (диаграмма № 2). Также музей вводил снижение на 50\% стоимости билета на выставку «Сокровища Долины царей. Царский курган Аржан-2». 
Из статистики экскурсий в Национальном музее РТ видно, что значительное количество посещений приходится именно на «Золотой зал». При этом каждый год прослеживается увеличение посещаемости как музея в целом, так и отдельно «Золотого зала» НМ РТ. Снижение количества посетителей в 2020 г. было обусловлено сложной эпидемиологической обстановкой в Туве и во всем мире - пандемией COVID-19.

Поскольку выставка «Золотого зала» пользуется особым интересом, то она имеет отдельную книгу отзывов и предложений. Первая запись в ней датируется 2020 г. Она содержит огромное число записей посетителей, мнения которых отражают положительные впечатления.

Приведём три отзыва последних месяцев 2020 года ${ }^{1}$ :

- «Большое спасибо за ваш великий труд! За прекрасную экспозицию [о золоте скифов]! Ворсина И., Алексеенко П., Моисеев А. (Красноярск)». 26 августа 2020 г.;

- «Мы очарованы музеем и комнатой “золото скифов”. Группа из Абакана», 20 сентября 2020 г.»;

- «Сокровища Долины царей» в Национальном музее Республика Тыва - место, которое обязательно нужно посетить, приезжая в Туву. Ведь эта экспозиция - одна из самых ярких достопримечательностей Кызыла, а может быть и всей Республики Тыва. В общем выставку “Сокровища Долины царей” обязательна к посещению. Где ещё можно вживую увидеть золото скифов, в таком идеальном состоянии? Наверное нигде. Спасибо Национальному музею Республики Тыва за возможность прикоснуться к истории», Дмитрий Вальцев, волонтёр РГО и участник Азиатской номадической экспедиции ИИМК РАН по исследованию кургана Туннуг в Пий-Хемском кожууне Республики Тыва, Санкт-Петербург, 07 декабря 2020.

Глава Республики Тыва Ш. В. Кара-оол также дал высокую оценку новому преобразованному «Золотому залу», поблагодарив коллектив НМ РТ.

Помимо этого приведём комментарии читателей интернет-издания The Siberian Times, в котором в 2016 г. вышла статья о скифском золоте Тувы² ${ }^{2}$ Автор рассказывает о сокровищах Долины царей Тувы и сопровождает текст серией фотографий с выставки «Золотого зала» НM РТ, под которым читатели оставили более двадцати комментариев:

- «У меня нет слов». Лоуренс Солкоски, Нью-Вестминстер, Британская Колумбия, Канада 28.09.2016;

- «Спасибо, что поделились этим фантастическим произведением истории и изысканными произведениями искусства в ювелирных украшениях». Тина К., США 16.02.2016;

- «Эти сокровища просто потрясающие. Спасибо, что показали нам их фотографии». Роб, Стивенидж, Великобритания 02.12.2016;

- «Фигуры очень красивые. Я бы хотел увидеть их сам. Я также согласен с тем, что изделия должны были создаваться мастерами». Питер Джон, США14.02.2016.

Статистические данные и впечатления посетителей, а также тех, кто смог ознакомиться золотом скифом только на фотографиях, показывают нам высокую востребованность подобной выставки. И это не удивительно, поскольку речь идёт о богатой коллекции изделий из золота, способной привлекать вниманий широкой общественности, понятной для людей практически любой культуры, вызывающей сильные человеческие эмоции.

\section{Влияние выставки на культурную жизнь}

Выставка золотой коллекции Аржан-2 в НМ РТ уже давно вышла за пределы экспозиционной жизни. Следы ее влияния на культурную жизнь республики и за пределы ее можно увидеть во многих сферах. Это: научные проекты; издательские проекты; выставочные проекты; медиапроекты; туристические проекты; сувенирная продукция; дизайнерские проекты; образовательные проекты; архитектурные проекты; театральные проекты.

Научные проекты. Практически каждый год в самой Туве, в российских научных центрах и за рубежом проводятся конференции, семинары, круглые столы, на которых обсуждаются проблемы сохранения культурного наследия, а в последнее десятилетие и вопросы использования и популяризации скифского наследия, найденного в Туве.

\footnotetext{
${ }^{1}$ Записи даются с небольшой редакторской правкой.

${ }^{2}$ Gertcyk O. Focus on Tuva: Stunning treasures - and macabre slaughter - in Siberia's Valley of the Kings [Электронный ресурс] // The Siberian Times. 2016. 11 February. URL: https://siberiantimes.com/science/casestudy/ features/f0212-focus-on-tuva-stunning-treasures-and-macabre-slaughter-in-siberias-prehistoric-valley-of-thekings/?comm_order=\&c_page=1\#comments (дата обращения: 11.09.2020).
} 
В 2012 г., например, в г. Кызыле прошла Международная научно-практическая конференция «Историко-культурное наследие народов Центральной Азии: перспективы развития и проблемы сохранения», посвященная 20-летию создания государственного органа по охране памятников истории и культуры в Республике Тыва и Году Российской истории ${ }^{1}$. Во время конференции были подведены предварительные итоги археологического полевого сезона 2012 г. Научный сотрудник Института археологии РАН И. В. Рукавишникова сообщила тогда о проведении впервые на территории Тувы фотосъемок с использованием аэростата. Съемки производились на археологических памятниках «Долины царей».

Одной из острых проблем остаётся нелегальная торговля древними артефактами, которая наносит колоссальный ущерб археологическому наследию. Пути решения подобных проблем, например, обсуждались на международной конференции «Археологи против “черных копателей”» в г. Берлине в 2014 г. ${ }^{2}$ Так, на этом совещании Г. Парцингер рассказал о своём личном опыте общения с нелегальными «конкурентами» в Пакистане, где на него и его коллег однажды даже направлялись автоматы. Поэтому и в 2001 г. после нахождения непотревоженной могилы в кургане Аржан-2 в Туве Парцингеру пришлось лично нанимать охрану, опасаясь грабителей.

В 2015 г. в Москве проходила международная научная конференция, посвящённая изучению Древней Скифии, собравшая специалистов в области скифологии (Медведев, 2016). Они обсуждали образ и историко-культурное наследие скифов. В 2017 г. в Туве проходила II Международная научнопрактическая конференция «Историко-культурное наследие народов Центральной Азии: перспективы развития и проблемы сохранения», приуроченная 25-летию создания государственного органа в сфере объектов культурного наследия Республики Тыва ${ }^{3}$ В НМ РТ ежегодно проводится круглый стол по итогам очередного археологического сезона в Туве ${ }^{4}$.

Таким образом, в научных мероприятиях (международные конференции, съезды учёных, круглые столы и др.), тема скифского наследия, затрагивается в контексте общей археологической науки, на ряду с древнекаменным периодом, античностью, средневековьем и др. периодами. Объясняется это, если в Туве, распространённостью памятников скифской культуры. Авторами отмечается, что весомый вклад в исследование скифской культуры в стране, целенаправленно занимаются ведущие научные учреждения, как Институт Археологии РАН г. Москва, Институт истории и материальной культуры РАН г. Санкт-Петербург, МГУ Исторический факультет, Государственный Эрмитаж и др.

Издательские проекты. В 2010 г. Национальный музей РТ выпустил набор открыток «Аржан-2» (фото 7).

В 2015 г. переиздан буклет «Аржан-2» на русском и английском языках. Текст составила О. О. Монгуш, заведующая отделом археологии НМ РТ, перевод с русского на английский язык осуществил А. Седен-Хуурак. Фото и дизайн М. Ч. Чооду, верстка Б. Чооду (фото 8).

Филиалы НМ РТ также выпускают издания: буклеты, путеводители и др. Планируется расширять деятельность по научным изданиям (книгам, сборникам, каталогам, методическим пособиям и др.).

Научно-издательским проектом также выступил сборник материалов III научно-практической конференции с международным участием, которая проходила с 23 по 25 мая 2019 г. «Ермолаевские чтения». В рамках направлений работы конференции рассматривались проблемы сохранения культурного наследия народов Тувы и Сибири, образовательные и воспитательные функции музеев,

\footnotetext{
${ }^{1}$ Международная научно-практическая конференция «Историко-культурное наследие народов Центральной Азии: перспективы развития и проблемы сохранения» [Электронный ресурс] // Новые исследования Тувы. 2012, № 4. URL: https://nit.tuva.asia/nit/article/view/297 (дата обращения: 22.09.2020).

${ }^{2}$ Археологи против «черных копателей» [Электронный ресурс] // DW. 2014, 15 декабря URL: https://www.dw.com/ ru археологи-против-черных-копателей/а-18129142? maca=rus-rss_rus yandex new comments_2-4163-xml (дата обращения: 22.09.2020).

${ }^{3}$ II Научно-практическая конференция «Историко-культурное наследие народов Центральной Азии: перспективы развития и проблемы сохранения», приуроченная 25-летию создания государственного органа в сфере объектов культурного наследия Республики Тыва. (2017) [Электронный ресурс] // Тувинский институт гуманитарных и прикладных социально-экономических исследований при Правительстве Республики Тыва. 2017, 24 октября. URL: https://tigpi.ru/214123/ (дата обращения: 22.09.2020).

${ }^{4}$ Круглый стол об итогах археологического сезона 2020 г. [Электронный ресурс] // Страница Национального музея PТ ВКонтакте. 2020, 4 сентября. URL: https://vk.com/museumtuva?w=wall-30861506_5349 (дата обращения: 22.09.2020).
} 

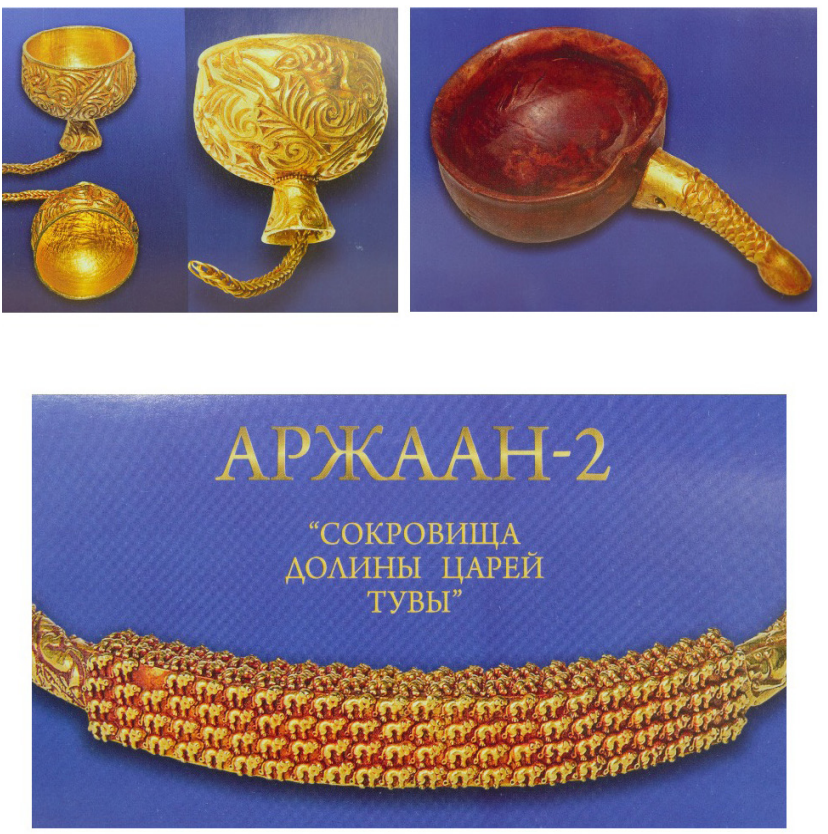

Фото 7. Набор открыток «Аржан-2». Фото А. Э. Мижит, 2021 г. Photo 7. "Arzhan II", a set of postcards. Photo by A. E. Mizhit, 2021.

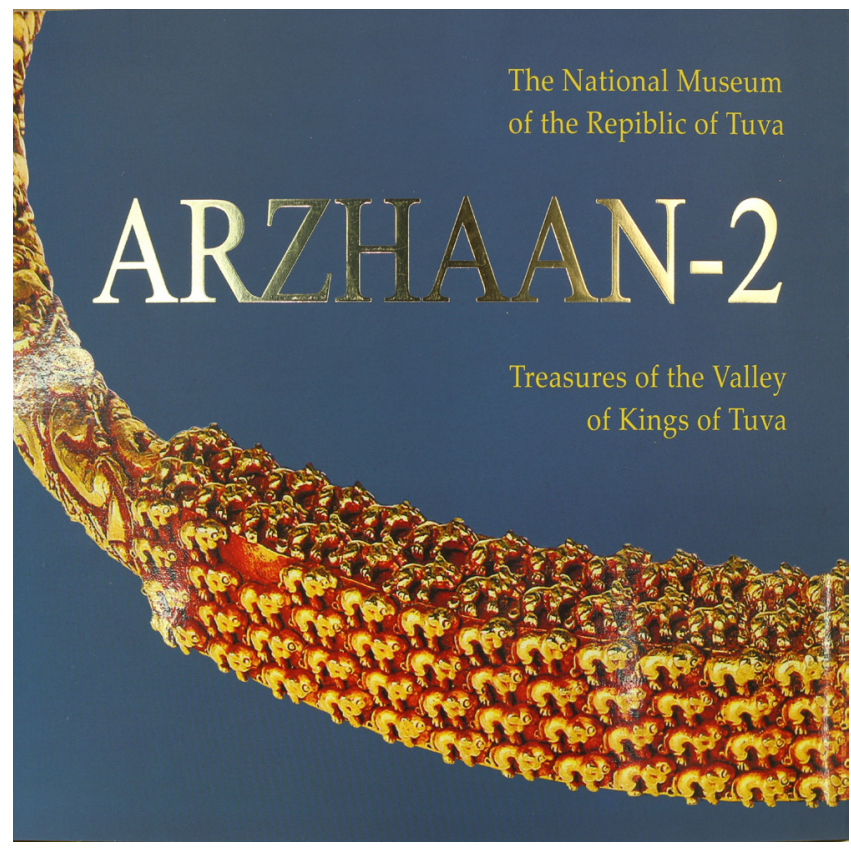

Фото 8. Обложка буклета «Аржан-2». Фото А. Э. Мижит, 2021 г.

Photo 8. Cover of "Arzhan II" booklet. Photo by A. E. Mizhit, 2021.

вопросы комплектования и экспонирования, а также перспективы развития музейного дела и т. д. (Ермолаевские чтения ..., 2019).

Bыставочные проекты. На протяжении всей истории музея обычной практикой является постоянное проведение выставок - стационарных, передвижных; тематических и пр.

Так, например, фотовыставка «Курган Аржан-2» проводилась в рамках работы международной конференции по проблемам сохранения культурного наследия под г. Саяногорском (2011). Также отметим проходившую 23-24 сентября 2016 г. в г. Улан-Удэ, столице Бурятии выставку «Мир скифосибирского звериного стиля: диалог культур» в Национальном музее Республики Бурятии. Основными экспонатами были гальванокопии золотых предметов из скифских курганов и предметы из чонар-дащ 1 .

С 4 по 15 марта 2016 г. в конференц-зале НМ РТ действовала выставка «Сокровища Долины царей Тувы» (фотографии А. Бронникова из Культурного фонд им. Кужугета Шойгу) и гальванокопии золотых предметов из кургана Аржан-2.

С 12 июля 2018 г. по настоящее время в НМ РТ работает фотовыставка немецкого фотографа Буркхарда Томанна «Двух миров одно мгновенье» («Zwei Welten, Ein Augenblick»). Это история в фотографиях, в которой сравниваются артефакты, найденные в 5000 километрах друг от друга - в Долине царей Тувы и в мире кельтов в Глауберге. Фотографии в соответствующих композициях показывают параллели между тувинской и немецкой землями.

Тувинский фоторепортаж был сделан Б. Томанном во время его работы в составе международной экспедиции, занимавшейся археологическими раскопками вдоль маршрута проекта «Кызыл - Курагино» в 2012 г. Позже Буркхарда заинтересовало наглядное соответствие многих черт в природе и др. явлений, возникших в результате разных исторических, географических, социальных, религиозных и политических условий. Благодаря выразительности кадра удалось показать схожие черты, практически зеркальное отражение двух народов и культур². Так родилась идея выставки³.

${ }^{1}$ Приглашаем гостей и жителей Бурятии на выставку «Мир скифо-сибирского звериного стиля: диалог культур» [Электронный ресурс] // Национальный музей Республики Бурятия. URL: http://2020.muzeyrb.ru/2016/09/21/priglashaem-gostey-i-zhiteley-buryatii-n/ (дата обращения: 22.09.2020).

${ }^{2}$ Буркхард Томанн: «Я - ловец уходящих мгновений»... [Электронный ресурс] // Тува.Азия. 2018, 15 июля. URL: https://www.tuva.asia/news/society/9253-burkhard-tomann-ya-lovec-uhodyaschih-mgnoveniy.html (дата обращения: 22.09.2020)

${ }^{3}$ Фотовыставка немецкого фотографа Буркхарда Томанна «Два мира, одно мгновение» [Электронный ресурс] // Страница Национального музея PT ВКонтакте. URL: https://vk.com/museumtuva?w=wall-30861506_2136 (дата обращения: 22.09.2020). 
Так, одним из эпизодов выставки стали фото коньков двух крыш с декоративными элементами (фото 9): конек слева украшает крышу здания Центра развития тувинской культуры и ремесел в Туве; конек справа находится в Германия. Автор показывает очевидное сходство между ними.

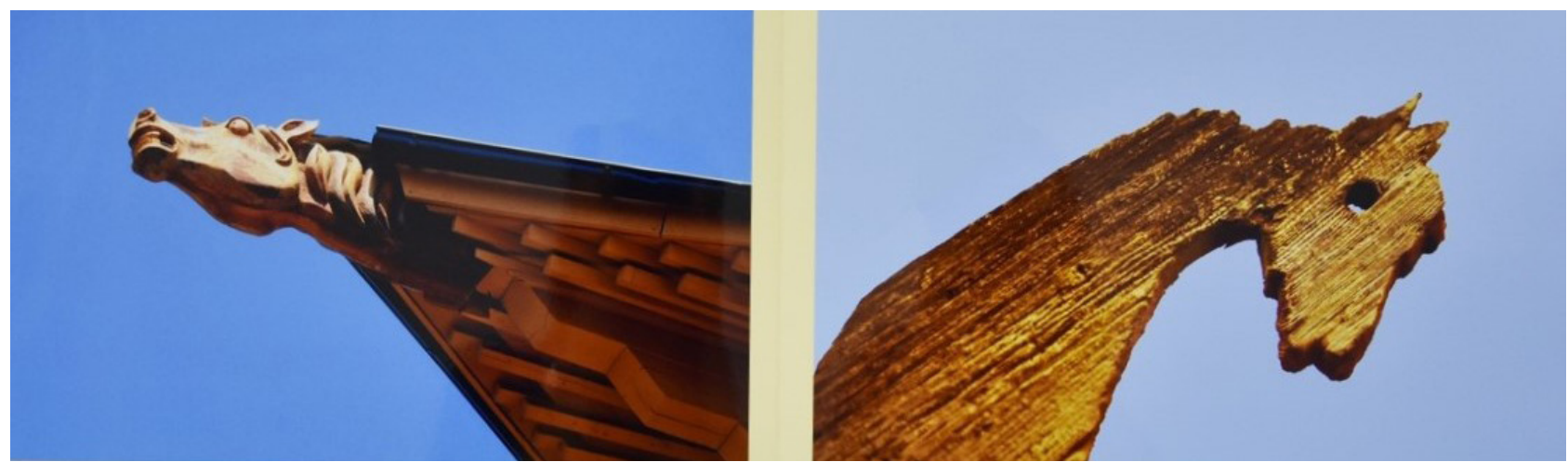

Фото 9. Две фотографии - один из элементов выставки «Два мира, одно мгновение». Фото Т. Буркхарда: слева - 2012 г., справа - 2016 г.

Photo 9. Two photographs as an element of the "Two worlds, one instant" exhibition. Photos by T. Burckhard, on the left - 2012, on the right - 2016.

Сотрудники НМ РТ подготовили в первом квартале 2019 г. выездную выставку «Золото скифов Долины царей» для городов Сибири. Первым городом, где была представлена выставка, стал г. Курагино Красноярского края. Здесь 27 сентября 2019 г. проходило юбилейное мероприятие к 55-летию Курагинского краеведческого музея. На выставке на витринах были представлены копии золотых изделий Аржан-2 ${ }^{1}$.

В 2019 г. приказом министра культуры Республики Тыва А. К. Тамдына создан филиал НМ РТ историко-культурный музей-заповедника «Долина царей». Первый этап с согласованием и упорядочиванием документов завершён. На втором этапе в четвёртом квартале 2020 г. разработан проект музеефикации «Царский курган Аржан-2».

В перспективе музей предусматривает дальнейшее расширение культурных связей через обменные выставочные проекты на межрегиональном и международном уровнях.

Медиапроекты (СМИ, телепрограммы, фильмы). В 2017 г. в Туву была приглашена команда кулинарной ТВ-программы «Поедем, поедим» федерального канала «НТВ» (ведущий Дж. Уоррен). Они побывали и на республиканских праздниках, в также снимали зал «Сокровища Долины царей Тувы. Аржан-2». Дж. Уоррен, представляя выставку в музее Тувы, сказал: «Оказывается, именно здесь (в Туве. - aвm.) найдена самая большая в мире коллекция золота скифов» ${ }^{2}$ Как нам сообщила смотритель У. Ы. Ондар, сопровождавшая гостя, ведущий был впечатлён уникальной коллекцией.

В 2019 г. японская вещательная корпорация NHK сняла документальный фильм о золотой коллекции Аржан-2 в НМ РТ специально для Олимпиады в Токио 2020 г. ${ }^{3}$ (режиссёр Кэндзи Морита). Было смонтировано два научно-популярных фильма (краткая и более полная версия): научно-популярный фильм «Iron Road: Путь неизвестной древней цивилизации» (демонстрировался в эфире в рубрике NHK Special 13 января 2020 г.) и научно-популярный фильм «Iron Road: Путь неизвестной древней цивилизации» в двух частях (демонстрировался 7 и 14 февраля 2020 г.). Создатели фильма приравняли значимость коллекции в тувинском музее к семи чудесам мира.

Туристические проекты. В 2017 г. НМ РТ разработал туристско-познавательный маршрут «Долина царей Тувы» с установкой 9 информационных модулей/стендов и 1 рекламным щитом. Автор проекта О. О. Монгуш, старший научный сотрудник отдела археологии НМ РТ. Научными консультантами на

${ }^{1} \mathrm{O}$ передвижной выставке в Курагинском районном краеведческом музее [Электронный ресурс] // Сайт Национального музея PT ВКонтакте. URL: https://vk.com/museumtuva?w=wall-30861506_4461 (дата обращения: 22.09.2020).

${ }^{2}$ Поедем, поедим! Тува [Электронный ресурс] // HTB. 2018, 18 августа. URL: https://www.ntv.ru/video/1627984 (дата обращения: 22.09.2020).

${ }^{3}$ Перенесена из-за пандемии на 2021 год. - ред. 
стадии подготовки проекта выступили И. Руковишникова (Институт археологии РАН) и К. Чугунов (Государственный Эрмитаж). Проект также оценили и поддержали сотрудники Департамента по образованию мэрии г. Кызыла и Тувинского института комплексного освоения природных ресурсов (ТИКОПР СО РАН).

На прочных устойчивых конструкциях, встроенных в каменные сооружения, располагаются тексты на трёх языках (русском, тувинском, английском), фотографии и схемы расположения захоронений эпохи скифов.

По словам автора О. О. Монгуш, которые она высказа-

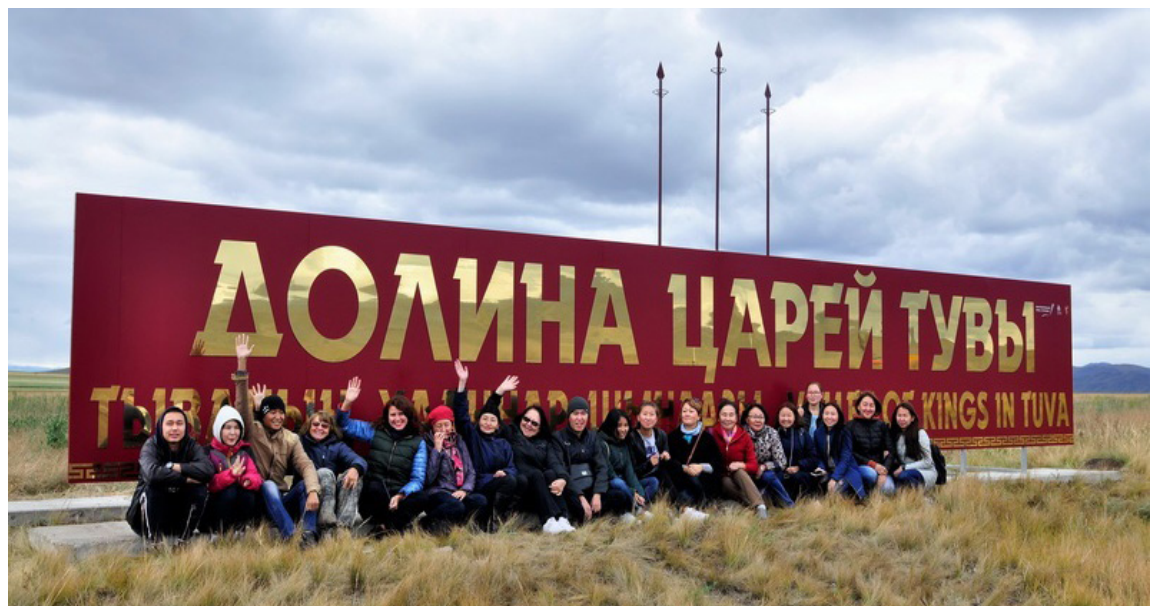

Фото 10. Преподаватели Тувинского госуниверситета, музейные работники, местные СМИ и др. на фоне вывески «Долина царей Тувы» на открытии нового туристско-познавательного марирута «Долина царей Тувы» в Пий-Хеме РТ. Фото Н. Дорошева, 20172.

Photo 10. Professors of Tuvan State University, museum researchers, journalists and others in front of the "Valley of the kings in Tuva" sign at the opening of the new tourist route "Valley of the kings in Tuva", Pii-Khem, Republic of Tuva. Photo by N. Doroshev, 2017. ла на презентации проекта 23 сентября 2017 г.: «Многие места на территории Тувы имеют сакральное значение. Наша задача сохранить эти места ещё на тысячу лет и научно популяризировать их таким образом, чтобы увести людей от потребительского отношения к познавательному и созидательному» ${ }^{1}$.

После мероприятия, которое прошло в НМ РТ, участники презентации выехали в Долину царей Тувы по созданному маршруту. Первыми туристами стали преподаватели истории и обществознания городского методического объединения г. Кызыла, преподаватели Тувинского государственного университета, студенты-историки, школьники, учёные-геологи, представители Центра тувинской традиционной культуры и ремёсел, СМИ и сотрудники НМ РТ (фото 10).

Тем самым музей создает не только экспозиции в своем здании, но и разрабатывает проекты создания музея под открытым небом.

Дизайнерские проекты. Музей не ведет статистики, но, по нашему мнению, происходит увеличение числа заявок от мастеров и дизайнеров по изучению музейных коллекций. Их работы пополняют и коллекции самого музея. Это коллекция национальной стилизованной одежды «Золото в чёрном» (фото 11) известного в Туве и за ее пределами дизайнера Ю. Хирбээ, руководителя модельного агентства «Урянхай»; шейное женское украшение гривна «Скифский олень» из черного и золотого японского бисера тохо - работа мастера декоративно-прикладного творчества, педагога дополнительного образования Е. В. Седип (2010 г.); скифская пантера, вышитая на подушках с национальным орнаментом мастером Э. А. Ооржак (фото 12).

Образовательные проекты. Основной контингент посетителей составляют школьники, студенты и туристы. Для школьников проводятся акции - ежемесячное бесплатное посещение каждую последнюю среду месяца. Помимо этого, музей вместе с образовательными и культурными учреждениями Республики Тыва проводит регулярно конкурсы стихов, легенд, рисунков и других творческих работ среди детей и взрослых.

Приведем в качестве примера вдохновенное стихотворение «В Долине царей»² Самыя Ай-Хаана, ученика 11 класса Кызылского президентского кадетского училища ${ }^{3}$ - участника конкурса «Мифы

${ }^{1}$ Долина царей Тувы приняла первых туристов [Электронный ресурс] // Сайт Благотворительного фонда Владимира Потанина. URL: https://www.fondpotanin.ru/press/news/dolina-tsarey-tuvy-prinyala-pervykh-turistov/ (дата обращения: 22.09.2020).

${ }^{2}$ Монгуш М. А. В Долине царей [Электронный ресурс] // Страница Национального музея PT BКонтакте. URL: https:// vk.com/museumtuva?w=wall-30861506_4645 (дата обращения: 10.12.2020).

3 Заведующий музеем Кызылского президентского кадетского училища МО РФ - Заслуженный работник культуры РТ, ветеран НМ РТ О. О. Монгуш. 


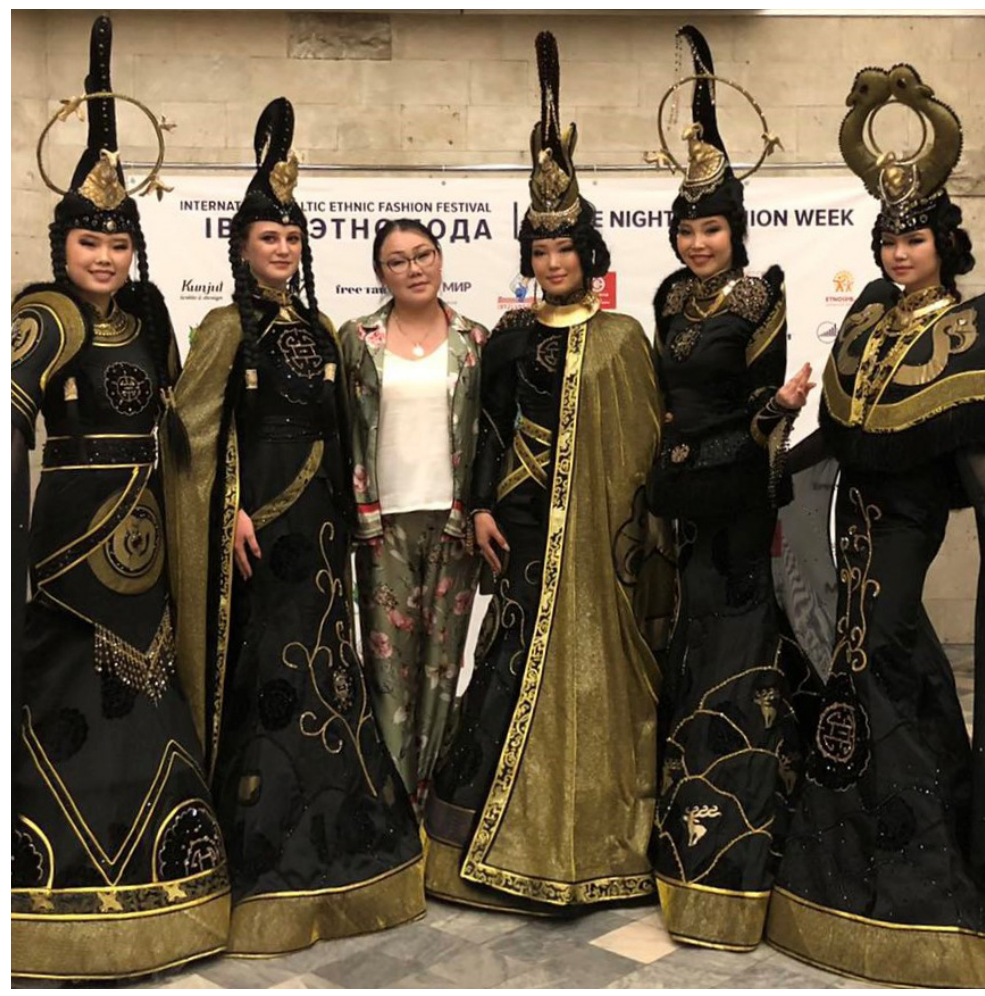

Фото 11. Ю. Р. Хирбээ с моделями Урянхай, коллекция национальной одежды «Золото в чёрном». Фото Ч. В. Ооржак, 2018 г.

Photo 11. Yu. R. Khirbee with Uryankhai agency models displaying the "Gold on black" collection of national wear. Photo by Ch. V. Oorzhak, 2018.

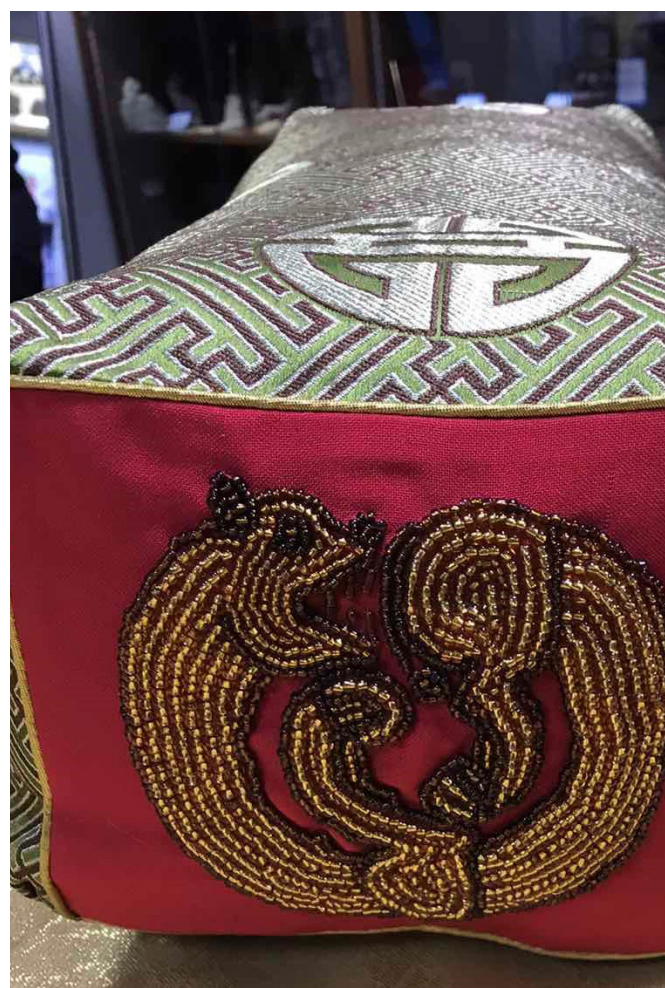

Фото 12. Тувинская подушка с вышитой пантерой. Фото Э. А. Ооржак, 2020 г.

Photo 12. A Tuvan pillow with a panther embroidery. Photo by E. A. Oorzhak, 2020.

и легенды Пий-Хема» 2019 г. Он был организован отделом по делам молодежи, культуры и спорта администрации Пий-Хемского кожууна и Центральной библиотечной системы 29 ноября:

\section{В Долине царей}

В долине Уюка, у подножия Саян

Курганы скифские загадки хранят

Любовь обрели здесь, затем покой,

В вечность шагнули царица с царем

\section{С чужих земель привезена}

«Царевна» - дочь соседнего вождя

В знак мира, дружбы подарена.

Владыки скифов она теперь жена.

Владыка тот захватчик, победитель

Племён сильнейший предводитель.

Царица краше всех, царю - отрада.

Прекрасная душой, любимая народом.
И правили годами, день ото дня

Даря заботу, радость лишь друг другу

Но тот час пришёл - не стало царя,

Остался народ как будто без отца.

Владычица скифов сочла же за честь

Пойти за любимым, ведь смерть - не конец.

Окутаны златом, мехами, серебром,

Уснули сном вечным царица с царём.

В долине Уюка, у подножия Саян

Курганы скифские загадки хранят

Любовь обрели здесь, затем покой,

В вечность шагнули царица с царём.

Театральные проекты. 22 марта 2017 г. в Национальном театре Тувы состоялась премьера му-

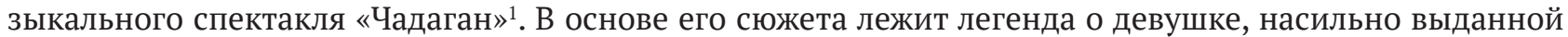
замуж и отказавшейся кормить грудью ребёнка от нелюбимого мужа (фото 13).

Постановка является совместным проектом Национального театра и Национального оркестра РТ. Автор - Александр Даржай, Народный писатель РТ. Режиссёр-постановщик - Сайдаш Монгуш,

${ }^{1}$ Музыкальная легенда «Чадаган» [Электронный ресурс] // Сайт Национального музыкально-драматического театра PT им. Виктора Кок-оола. URL: http://theatre-tuva.ru/o-teatre/repertuar/chadagan.html (дата обращения: 22.09.2020). 
Заслуженный артист РТ. В ходе подготовки спектакля он неоднократно посещал исследованную территорию кургана Аржан-2 и «Золотой зал» НМ РТ.

На премьере присутствовало много представителей тувинской интеллигенции. Одна из зрителей театральный критик А. К. Кужугет отметила обращение к скифскому прошлому, которое, по ее мнению, «добавило особую колоритность повествованию» 1.

Музыкальная легенда пользуется популярностью среди населения. Спектакль идёт на тувинском языке с синхронным переводом на русский язык.

Сувенирные проекты. Большим спросом среди гостей и жителей Республики Тыва пользуется сувенирная продукция, представляющая золотые находки скифского времени. Ее производством и продажей занимаются: Национальный музей РT, Центр развития тувинской традиционной культуры и ремёсел, ряд предпринимателей и предприятий (например, ООО «Шевер» и др.). Спросом пользуются изображения, копии золотых предметов, оформленные в багетные рамки, а также продукция предпринимателя В. Балчий-оола (фото 14) и др.

Подобные картины, предметы украшают как помещения представителей официальной власти (правительства, парламента, министерств, органов самоуправления и т. д.), так и дома частных лиц. Также готовятся под заказы календари, буклеты, брелоки, магнитики, значки и прочая продукция на тему скифского золота.

В 2019 г. руководитель дизайн-студии «Субедей» (г. Кызыл) С. Н. Самдан по заказу Министерства экономики РТ разработал сувенирный набор «Скиф-

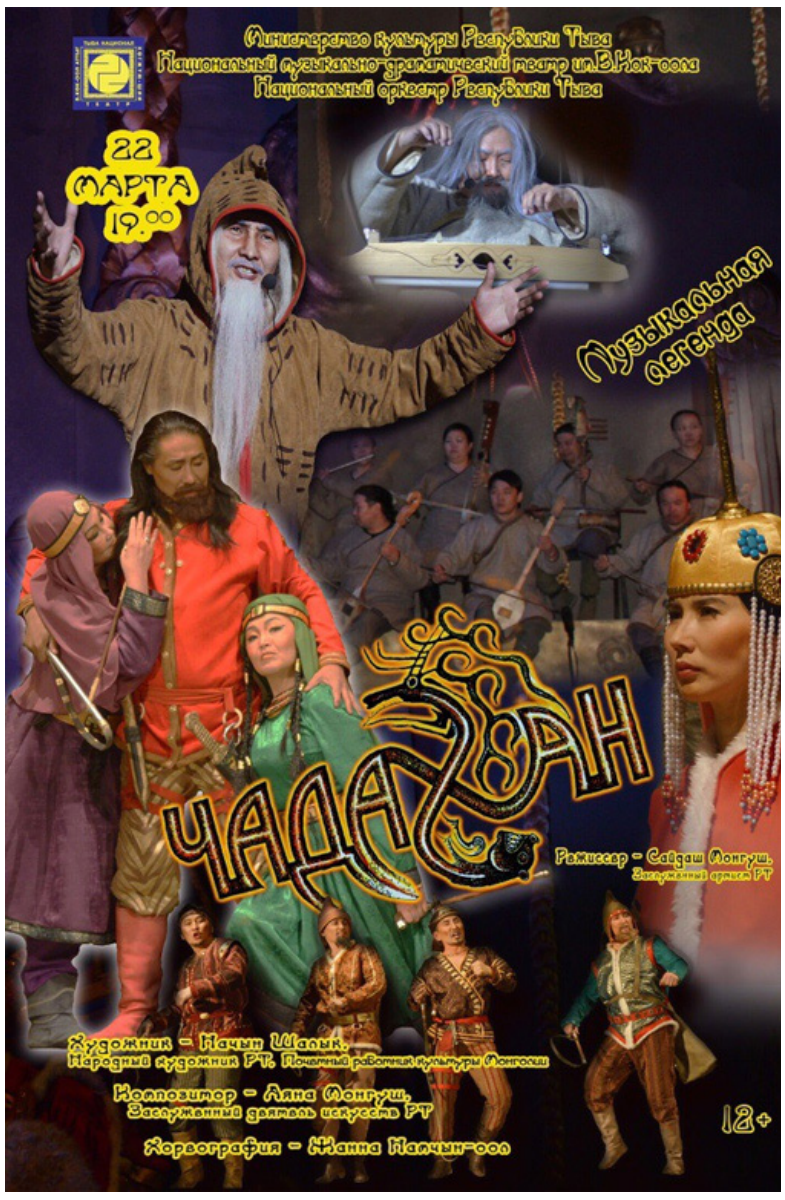

Фото 13. Афиша спектакля «Чадаган». Художник Н. Шалык, 2017 г.

Photo 13. The poster for the performance of "Chadagan", by N. Shalyk, 2017. ские снежинки» в виде прозрачных снежинок, где посередине располагаются золотые животные из курганов Аржан-1 и Аржан-2 (фото 15). С. Н. Самдан также выступает автором календарей и другой продукции.

Предприниматели Тувы с большой охотой используют образы скифских артефактов, поскольку сувенирная продукция с ними пользуется спросом. Ее заказывают и сам музей, и органы государственной власти; с удовольствием приобретают как гости столицы, так и жители самой республики.

Однако, вопрос соблюдения авторских прав относительно образов скифских изделий, хранящихся в главном музее Тувы, пока практически не решается.

Архитектурные, скульптурные проекты. Одним из красивых и важных достопримечательностей г. Кызыла сегодня считается обелиск «Центр Азии» (фото 16), который обозначает географический центр азиатского материка и находится у слияния рек Каа-Хема и Бий-Хема, образующего реку Енисей. Новый обелиск построен в 2014 г. к 100-летию единения Тувы и России по проекту бурятского художника Даши Намдакова. Рядом с обелиском установлена скульптурная композиция «Царская охота» (фото 17), и ресторан тувинской кухни с одноименным названием.

За основу и стилистическое оформление обелиска были взяты сюжет и образы золотых находок из Аржан-2. Вдохновение мастер получил именно из этой темы. Вот как он рассказывает о своей творческой находке:

${ }^{1}$ Монгуш Виктория (2017) Спектакль о скифском царе поставили в Туве // [Электронный ресурс] // Сайт Движение. Новые скифы. URL: http://newskif.su/2017/4605/ (дата обращения: 10.12.2020) 


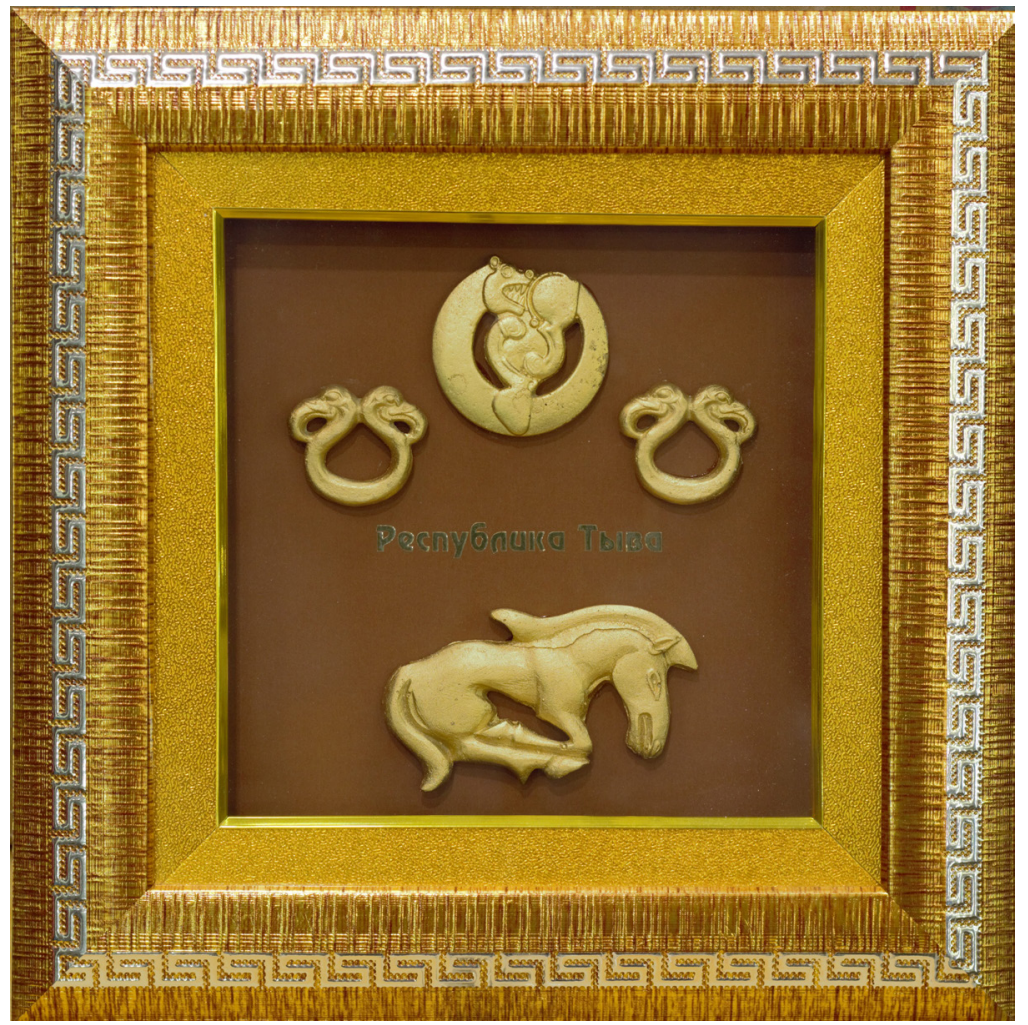

Фото 14. Изображения золотых изделий в рамке, автор В. Балчий-оол. Фото А. Э. Мижит, 2021 г.

Photo 14. Images of gold jewellery in a frame, by V. Balchiy-ool. Photo by A. E. Mizhit, 2021.

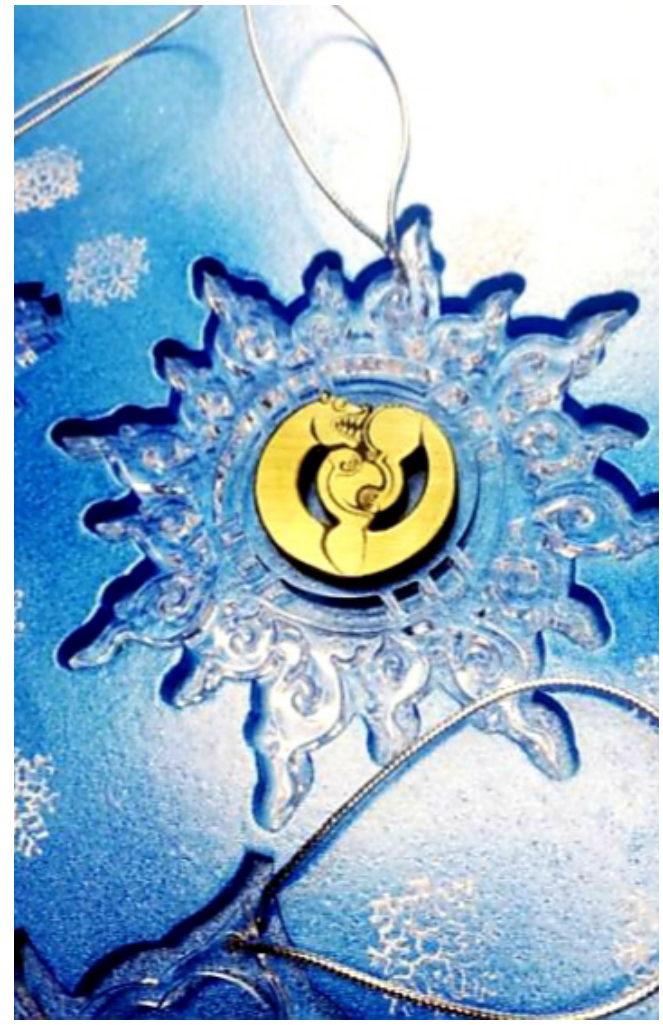

Фото 15. Снежинки Скифское золото Тувы. Пантера. Автор дизайна и фото С. Н. Самдан, 20192.

Photo 15. Snowflakes with images of the Scythian gold of Tuva: a panther. Design and photo by S. N. Samdan, 2019.

- После звонка Сергея Кужугетовича я приехал, познакомился с Главой республики. С группой людей неравнодушных к республике, к городу мы провели мозговой штурм. Затем я сходил в Национальный музей, посмотрел артефакты. Хотя я уже их знал, часть видел в Эрмитаже.

Но то, что я увидел здесь, пики и так далее, у меня сразу в голове выскочило “Вот! И не надо ничего искать. Все лежит на поверхности просто надо собрать эти пазлы”, - довольно лаконично дополнил Намдаков ${ }^{1}$.

В Кызыле теперь нередко встречаются стилистически оформленные внутренние стены и потолки зданий с элементами скифской культуры. К примеру, это мы можем увидеть в здании Центра развития тувинской традиционной культуры и ремёсел (ул. Ленина, д. 7), во внутреннем оформлении здания самого Национального музея имени Алдан-Маадыр Республики Тыва (ул. Титова, д. 30) (фото 18).

Дизайн-студия «Субудей» выполнила для музея также стилизованную трибуну в 2018 г. для конференц-зала (фото 19).

Также интересны работы художников-скульпторов - участников республиканского конкурса «Уран-Балды», проходившего в сентябре 2020 г. Он был посвящён к 75-летию Победы в Великой Отечественной войны и 100-летию Тувинской Народной Республики. Три работы конкурсантов, где за основу творения были взяты археологические предметы из раскопок скифских погребений, стали украшением выставочных залов музея, в том числе и зала золота. Это скульптуры: «Мөңге шак» (фото 20), автор Х. О. Ооржак; «Скифский трон» (фото 21), автор Ч. В. Соян и «Скифская пантера» (фото 22), автор Б. В. Ооржак.

Таким образом, влияние скифских находок на современную культурную жизнь Тувы очень значимо и его можно обнаружить практически во всех сферах. Более того, оно перешагивает за пределы самой республики. Интерес к скифскому золоту, великолепию древних находок во взаимосвязи с названием

${ }^{1}$ Скульптор Даши Намдаков: Произведение «Центр Азии» - это роман [Электронный ресурс] // Тува.Азия. 2016,

21 июля. URL: https://www.tuva.asia/news/tuva/8734-namdakov.html (дата обращения: 25.11.2020). 


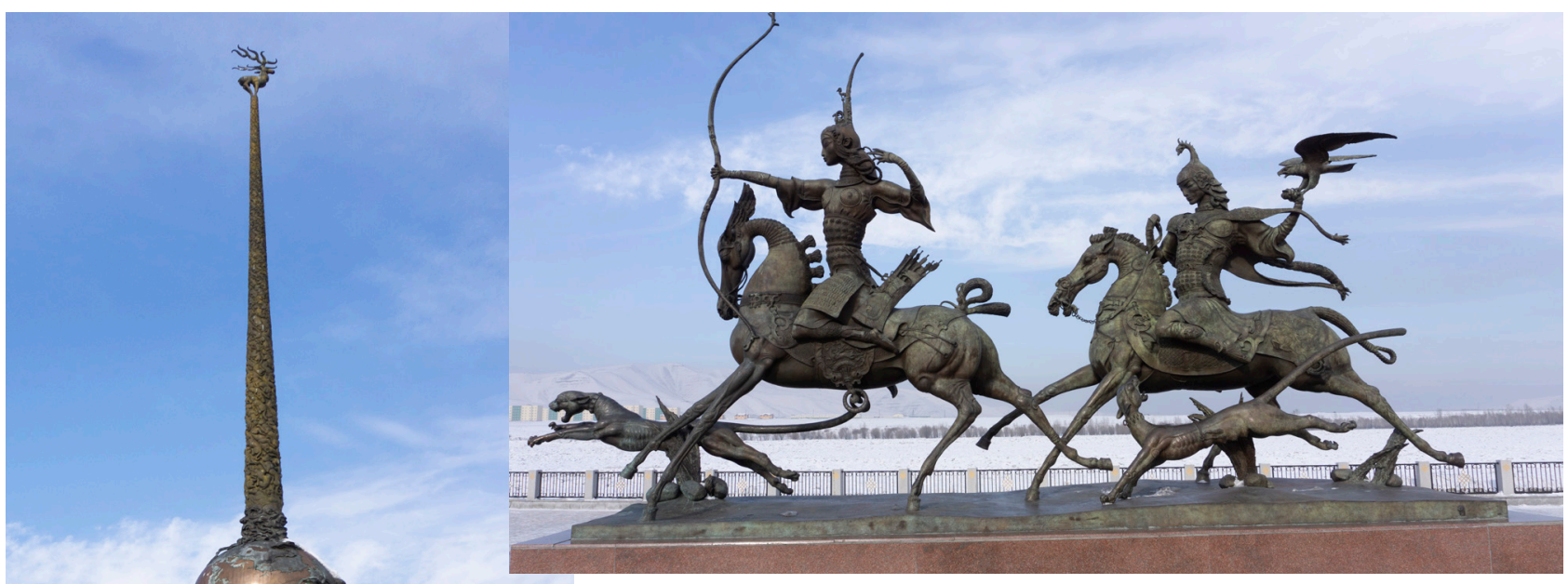

Фото 16 и 17. Обелиск «Центр Азии»

и скульптурная композиция Д. Намдакова «Царская охота» возле обелиска «Центр Азии».

Фото М. А. Монгуш, 2021 г.

Photo 20. D. Namdakov's the "Center of Asia" obelisk and "The royal hunt", a sculptural group. Photo by M. A. Mongush, 2021.

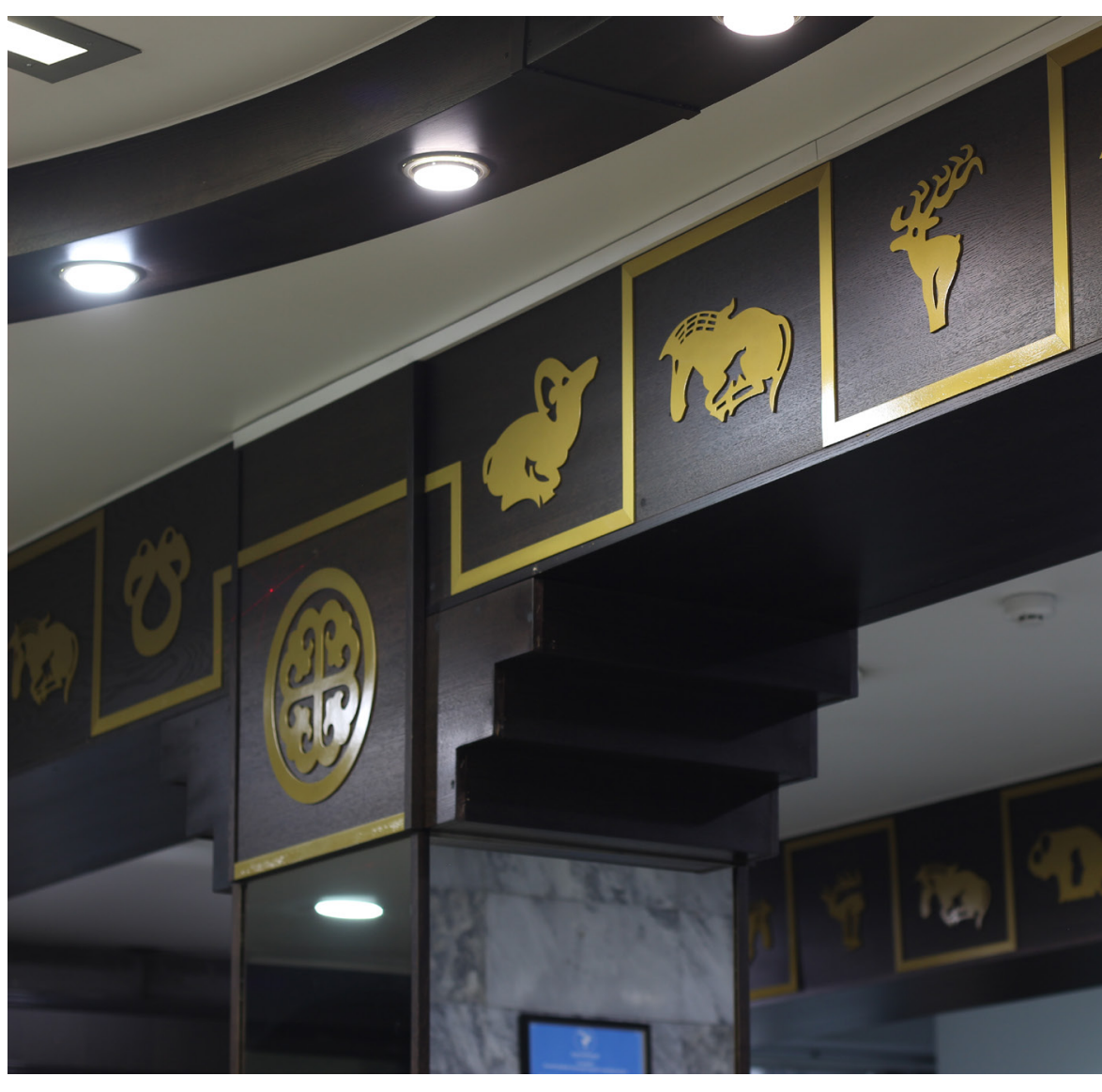

Фото 18. Несущие колоны и потолок НМ РТ. Фото А. Э. Мижит, 2020 г.

Photo 22. The supporting column and the ceiling of the NM RT. Photo by A. E. Mizhit, 2020.

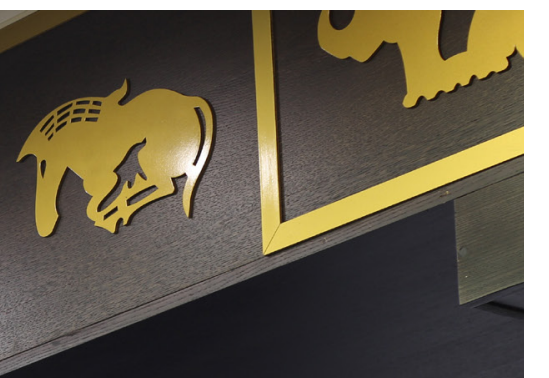

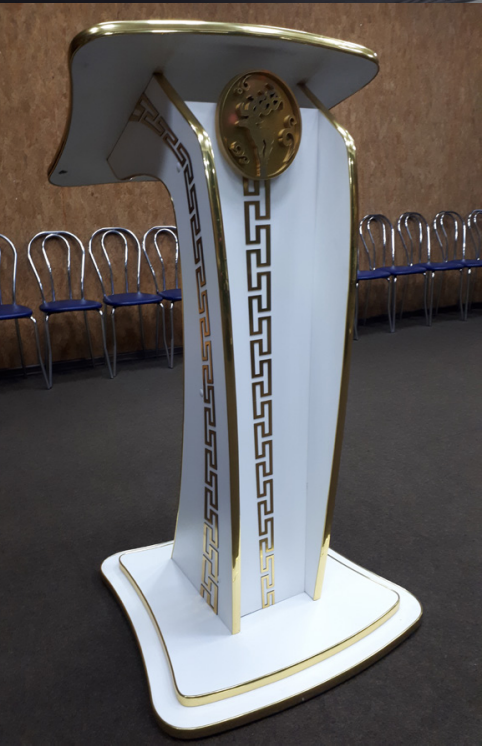

Фото 19. Трибуна с эмблемой НМ РТ. Автор дизайна С. Н. Самдан. Фото М. А. Монгуш 2020 г.

Photo 19. A stand with the logo of NM RT, designed by S. N. Samdan. Photo by M. A. Mongush, 2020. 

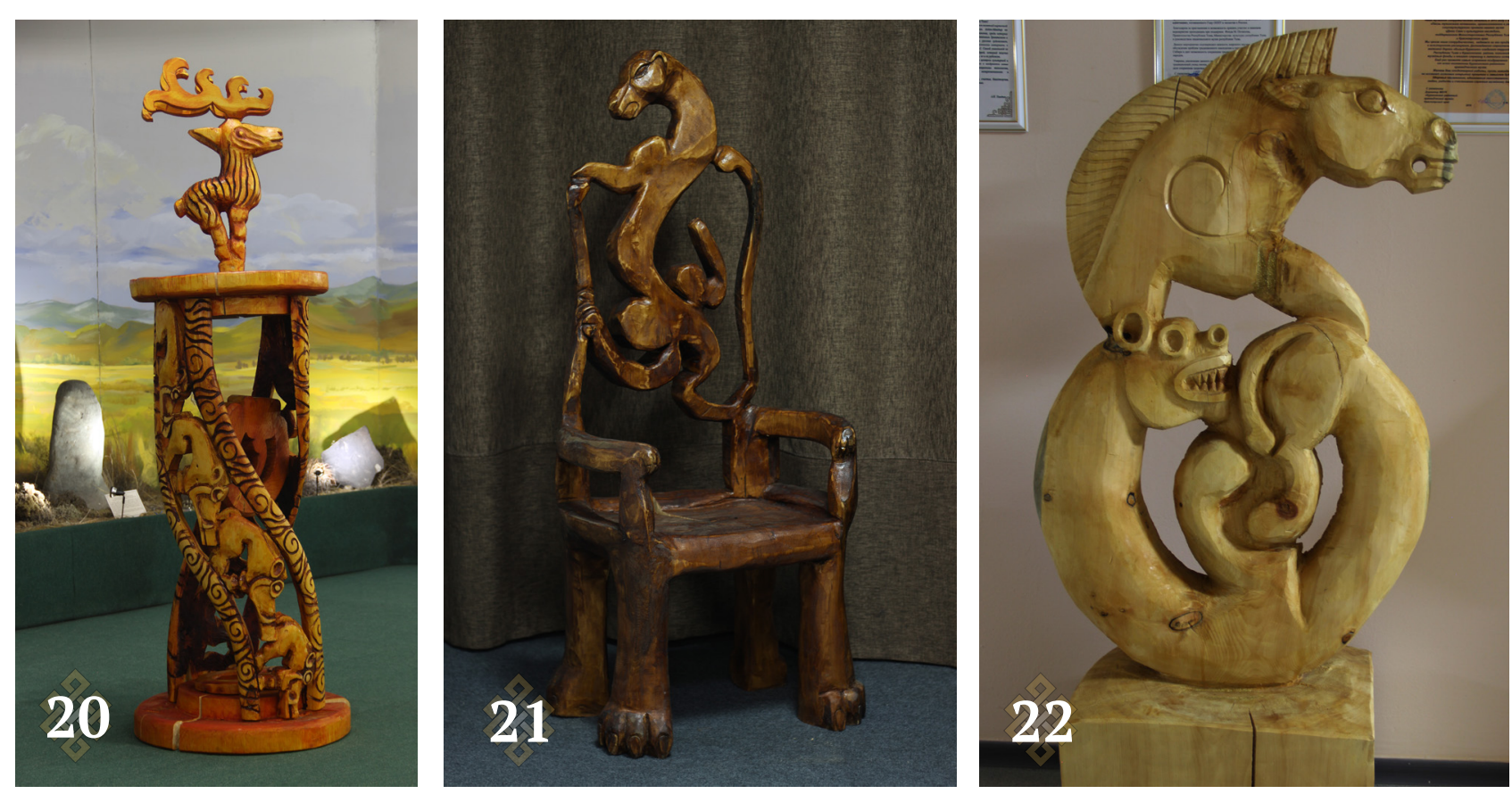

Фото 20-22. Скульптуры из дерева: 20 - «Монге шак», автор Х. О. Ооржак; 21 - «Скифский трон», автор Ч. В. Соян; 22 - «Скифская пантера», автор Б. В. Ооржак. Фото А. Э. Мижит, 2020 г.

Photo 20-22. Wooden sculptures: 20 - "Monge Shak" by Kh. O. Oorzhak; 21 - "The Scythian throne” by Ch. V. Soyan; 22 - "The Scythian panther" by B. V. Oorzhak. Photo by A. E. Mizhit, 2020.

республики «Тува», «Тuva», позволяет рассматривать эту коллекцию как культурный бренд территории, распространяющийся по всему миру.

\section{Заключение}

Мы показали в статье историю становления и особенности содержания центральной экспозиции Национального музея Республики Тыва - золотой коллекции Аржан-2, которая имеет значительное влияние на культурную жизнь Тувы, а также на внешние культурные связи республики.

В перспективе работы музея по брендированию коллекции будут происходить интенсивнее и включат в себя организацию обменных выставок, создание дополнительных гальванокопий золотых предметов, создание манекенов и реконструкции одежды вельмож по версии тувинских мастеров, музеефикацию кургана Аржан-2, составление каталога кургана Аржан-1 и мн. др.

Очевидно, что коллекция может определять развитие в регионе и археологического туризма, поскольку вызывает и новые ожидания от изучения территории.

В целом, сама по себе данная выставка уже стала значительным явлением, может называться культурным брендом, «визитной карточкой» Тувы. Поэтому ее изучение важно для исследований культурологии, антропологии, социологии и даже политологии Тувы.

\section{Благодарности}

Авторы благодарят директора Национального музея им. Алдан-Маадыр Республики Тыва, доктора филологических наук Каадыр-оола Алексеевича Бичелдея за организационную поддержку. Также авторы выражают благодарность коллегам - сотрудникам музея, которые участвовали в реэкспозиции «Золотого зала» НМ РТ.

\section{СПИСОК ЛИТЕРАТУРЫ}

Аржан. Источник в Долине царей. Археологические открытия в Туве (2004) / под общ. науч. ред. М. Б. Пиотровского. СПб. : Славия. 64 с. $113 \mathrm{c}$.

Дыртык-оол, А. О. (2009) Музейное строительство Тувы в составе Российской Федерации. Кызыл : КЦО Аныяк.

Дыртык-оол, А. О. (2013) История создания археологической экспозиции в Национальном музее Республики Тыва // Вестник Тувинский государственный университет. Социальные и гуманитарные науки. № 1 (16). С. 11-18. 
Грязнов, М. П., Маннай-оол, М. Х. (1975) Курган Аржан по раскопкам 1973-1974 гг. // Ученые записки ТНИИЯлИ. Вып. 17 / отв. ред. Н. А. Аранчын. Кызыл : Тув. книж. изд-во. 208 с. С. 185-198.

Ермолаевские чтения: материалы III научно-практической конференции с международным участием (23-25 мая 2019 г.), посвященной 90-летию со дня основания Национального музея им. Алдан-Маадыр Республики Тыва (2019) / сост. О. Ю. Иргит. Кызыл : Типография МБОУ КЦО «Аныяк». 256 с.

Кудажы, Л. М., Опей-оол, У. П. (2009) Национальный музей им. Алдан-Маадыр Республики Тыва. Красноярск : Поликом. 96 с.

Килуновская, М. Е. (2012) Мониторинг археологических памятников Республики Тыва // Археологические памятники России: охрана и мониторинг. Группа археологического мониторинга ИИМК РАН (2001-2010). СПб. : Инфо Ол. 176 с. С. $102-175$.

Медведев, А. П. (2016) Научная конференция «Скифия: образ и историко-культурное наследие» // Вестник ВГУ. Серия: История. Политология. Социология. № 3. С. 124-125.

Монгуш, О. О. (2006) Скифо-сибирский звериный стиль в коллекциях Тувинского музея (на примере кургана Аржан-1) // Культура Тувы: прошлое и настоящее: сб. материалов науч.-практ. конф. (г. Кызыл, 3 марта, 31 марта 2004 г.) / ред. сост. И. В. Подик. Кемерово : КемГУКИ. 223 с. С. 42-45.

Нурзат, У. Б. (2013) «Золотой» зал Национального музея Республики Тыва: [к 5-летию открытия постоянной выст. «Сокровища Долины царей Тувы. Царский курган Аржаан-2»]// Люди и события Тувы: календарь-хронограф/ сост. Л. М. Чадамба, Е. М. Ак-Кыс. Кызыл : ГБУ «НБ им. А. С. Пушкина РТ». 115 с. С. 51-53.

Пименова, К. В. (2019) Сакральные предметы и трансформации музейной этики: истоки, проблемы, решения // Новые исследования Тувы. № 2. C. 115-127. DOI: 10.25178/nit.2019.2.10

Толковый словарь тувинского языка (2003) / под ред. Д. А. Монгуша. Новосибирск: Наука. Т. І: А-Й. 597 с.

Семенов, В. А., Килуновская, М. Е., Монгуш, О. О. (2014) Музей и вопросы сохранения, изучения и использования культурного наследия // Материалы научно-практической конференции (с международным участием), посвящённой 85-летию основания Национального музея Республики Тыва, 105-летию со дня рождения советского специалиста Николая Михайловича Богатырева и 100-летию единения России и Тувы / сост. А. О. Дыртык-оол, М. М. Мандан-Хорлуу. Новосибирск : ИД «Сибирские огни». 312 с. С. 67-71.

Чугунов, К. В. (2004) Звериный стиль кургана Аржан-2: к постановке проблемы // Изобразительные памятники: стиль, эпоха, композиции. Материалы тематической научной конференции / отв. ред. Д. Г. Савинов СПб. : Исторический факультет СПбГУ. 346 с. С. 273-276.

Чугунов, К. В. (2008a) Некоторые особенности искусства кургана Аржан 2 // Труды II (XVIII) Всероссийского археологического съезда в Суздале. Т. ІІ / отв. ред. А. П. Деревянко, Н. А. Макаров. М. : ИА РАН. 472 с. С. 98-101.

Чугунов, К. В. (2008b) Искусство звериного стиля из кургана Аржан-2 // Урянхай. Тыва Дептер: антология в 7 т. / под ред. С. К. Шойгу. М. : Слово. Т. 7. Древности Тувы. Археологические памятники (бронзовый век - конец ХIХ века). 904 с. С. $842-861$.

Чугунов, К. В. (2010) Янтарь среди золота кочевнических владык. Царский курган раннескифского времени Аржан-2 в Туве // Янтарь в древних культурах. Художественные произведения из собрания Государственного Эрмитажа. Каталог выставки / общ. науч. ред. М. Б. Пиотровского. СПб. : Славия. 144 с. С. 47-53.

Чугунов, К. В., Парцингер, Г., Наглер, А. (2017) Царский курган скифского времени Аржан-2 в Туве. Новосибирск : Изд-во ИАЭТ СО РАН. 500 с.

Ховалыг, Р. Б. (2009) К истории возвращения археологической коллекции «Аржаан-2» в фонды Национального музея им. Алдан-Маадыр Республики Тыва // Наследие народов Центральной Азии и сопредельных территорий: изучение, сохранение и использование: материалы Междунар. науч.-практ. конф., г. Кызыл, 9-10 сент. 2009 г.: в 2-х ч. / отв. ред. В. С. Чигжит; сост.: У. Б. Нурзат; науч. ред.: У. П. Опей-оол. Кызыл : типография КЦО «Аныяк». Ч. 2. 199 c. C. $149-152$.

Дата поступления: 15.12.2020 2.

\section{REFERENCES}

Arzhan. Istochnik v Doline tsarei. Arkheologicheskie otkrytiia v Tuve [Arzhan. A spring in the Valley of Kings. Archaeological discoveries in Tuva] (2004) / ed. by M. B. Piotrovskogo. St. Petersburg, Slaviia. 64 p. (In Russ.).

Dyrtyk-ool, A. O. (2009) Muzeinoe stroitel'stvo Tuvy v sostave Rossiiskoi Federatsii [Museum-building in Tuva as part of the Russian Federation]. Kyzyl, KTsO Anyiak. 113 p. (In Russ.).

Dyrtyk-ool, A. O. (2013) Istoriia sozdaniia arkheologicheskoi ekspozitsii v Natsional'nom muzee Respubliki Tyva [The history of the creation of the archaeological exhibits of the National Museum of the Republic of Tuva]. Vestnik Tuvinskii gosudarstvennyi universitet. Sotsial'nye i gumanitarnye nauki, no. 1 (16), pp. 11-18. (In Russ.).

Griaznov, M. P. and Mannai-ool M. Kh. (1975) Kurgan Arzhan po raskopkam 1973-1974 gg. [The Arzhan mound in the 1973-1974 excavations]. In: Uchenye zapiski TNIIIaLI. Vol. 17 / ed. by N. A. Aranchyn. Kyzyl, Tuvan book publisher. 208 p. Pp. 185-198. (In Russ.).

Ermolaevskie chteniia [The Ermolaev readings] (2019): Proceedings of the 3rd research conference with international participation (May 23-25, 2019), dedicated to the 90th anniversary of the founding of the Aldan Maadyr National Museum of the Republic of Tuva / comp. by O.Yu. Irgit. Kyzyl, Tipografiia MBOU KTsO «Anyiak». 256 p. (In Russ.). 
Kudazhy, L. M. and Opei-ool, U. P. (2009) Natsional'nyi muzei im. Aldan-Maadyr Respubliki Tyva [Aldan Maadyr National Museum of the Republic of Tyva]. Krasnoyarsk, Polikom. 96 p. (In Russ.).

Kilunovskaya, M. E. (2012) Monitoring arkheologicheskikh pamiatnikov Respubliki Tyva [Monitoring archaeological monuments of the Republic of Tuva]. In: Arkheologicheskie pamiatniki Rossii: okhrana i monitoring. Gruppa arkheologicheskogo monitoringa IIMK RAN (2001-2010) [Archaeological sites in Russia: security and monitoring. Archaeological monitoring group at the Institute for the History of Material Culture, RAS (2001-2010)]. St. Petersburg, Info Ol. 176 p. Pp. 102-175. (In Russ.).

Medvedev, A. P. (2016) Nauchnaia konferentsiia «Skifiia: obraz i istoriko-kul'turnoe nasledie» [Research conference "Scythia: Image and historical and cultural heritage"]. Vestnik VGU. Seriia: istoriia. Politologiia. Sotsiologiia, no. 3, pp. 124-125. (In Russ.).

Mongush, O. O. (2006) Skifo-sibirskii zverinyi stil' v kollektsiiakh Tuvinskogo muzeia (na primere kurgana Arzhan-1) [Scythian-Siberian animal style in the collections of the Tuva Museum: the case of Arzhan I mound)]. In: Kul'tura Tuvy: proshloe i nastoiashchee [Culture of Tuva: past and present]: Proceedings of a research conference (Kyzyl, March 3, March 31, 2004) / red. sost.: I. V. Podik. Kemerovo, KemGUKI. 223 p. Pp. 42-45. (In Russ.).

Nurzat, U. B. (2013) «Zolotoi» zal Natsional'nogo muzeia Respubliki Tyva: k 5-letiiu otkrytiia postoiannoi vyst. «Sokrovishcha Doliny tsarei Tuvy. Tsarskii kurgan Arzhaan-2» [The "Golden Hall” of the National Museum of the Republic of Tyva: the 5th anniversary of the opening of the permanent exhibition "Treasures of the Valley of the Kings of Tuva. Royal mound Arzhaan II”]. In: Liudi i sobytiia Tuvy: kalendar'-khronograf [People and events of Tuva: a calendar and chronograph] / comp. by L. M. Chadamba and E. M. Ak-Kys. Kyzyl, GBU «NB im. A. S. Pushkina RT». 115 p. Pp. 51-53. (In Russ.).

Pimenova, K. V. (2019) Sakral'nye predmety i transformatsii muzeinoi etiki: istoki, problemy, resheniia [Sacred objects and transformations of museum ethics: origins, problems, solutions]. New Research of Tuva, no. 2, pp. 115-127. (In Russ.). DOI: https://doi.org/10.25178/nit.2019.2.10

Tolkovyi slovar' tuvinskogo yazyka [An explanatory dictionary of the Tuvan language] (2003) / ed. by D. A. Mongush. Novosibirsk, Nauka. Vol. 1. 597 p. (In Russ. and Tuv.).

Semenov, V. A., Kilunovskaya, M. E. and Mongush, O. O. (2014) Muzei i voprosy sokhraneniia, izucheniia i ispol'zovaniia kul'turnogo naslediia [Museum and issues of preservation, study and use of cultural heritage]. In: Materialy nauchnoprakticheskoi konferentsii (s mezhdunarodnym uchastiem), posviashchennoi 85-letiiu osnovaniia Natsional'nogo muzeia Respubliki Tyva, 105-letiiu so dnia rozhdeniia sovetskogo spetsialista Nikolaia Mikhailovicha Bogatyreva i 100-letiiu edineniia Rossii i Tuvy [Proceedings of the research conference (with international participation) dedicated to the 85th anniversary of the founding of the National Museum of the Republic of Tuva, and the 105th anniversary of the Nikolai Mikhailovich Bogatyrev and the 100th anniversary of the union of Russia and Tuva] / comp. by A. O. Dyrtyk-ool and M. M. Mandan-Khorluu. Novosibirsk, ID «Sibirskie ogni». 312 p. Pp. 67-71. (In Russ.).

Chugunov, K. V. (2004) Zverinyi stil' kurgana Arzhan-2: k postanovke problemy [Animal style of kurgan Arzhan II: stating the problem]. In: Izobrazitel'nye pamiatniki: stil', epokha, kompozitsii [Pictorial monuments: style, epoch, compositions]. Proceedings of a research conference / ed. by D. G. Savinov. St. Petersburg, Istoricheskii fakul'tet SPbGU. 346 p. Pp. 273-276. (In Russ.).

Chugunov, K. V. (2008a) Nekotorye osobennosti iskusstva kurgana Arzhan 2 [Some features of the art of mound Arzhan II kurgan]. In: Trudy II (XVIII) Vserossiiskogo arkheologicheskogo s'ezda $v$ Suzdale [Works of the $2^{\text {nd }}$ (18 $\left.{ }^{\text {th }}\right)$ All-Russian Archaeological Congress in Suzdal]. Vol. II / ed. by A. P. Derevianko and N. A. Makarov. Moscow, IA RAN. 472 p. Pp. 98-101. (In Russ.).

Chugunov, K. V. (2008b) Iskusstvo zverinogo stilia iz kurgana Arzhan-2 [The art of animal style from mound Arzhan II]. In: Uriankhai. Tyva Depter: antologiia [Uriankhai. Tuvan notebook] : in 7 vols. / comp. by S. K. Shoigu. Moscow, Slovo. Vol. 7. Drevnosti Tuvy. Arkheologicheskie pamiatniki (bronzovyi vek - konets XIX veka) [Antiquities of Tuva. Archaeological sites (Bronze age - the end of the $19^{\text {th }}$ century)]. 904 p. Pp. 842-861. (In Russ.).

Chugunov, K. V. (2010) Iantar' sredi zolota kochevnicheskikh vladyk. Tsarskii kurgan ranneskifskogo vremeni Arzhan-2 $\mathrm{v}$ Tuve [Amber among the gold of nomadic lords. Early Scythian royal mound Arzhan II in Tuva]. In: Iantar'v drevnikh kul'turakh. Khudozhestvennye proizvedeniia iz sobraniia Gosudarstvennogo Ermitazha. Katalog vystavki [Amber in ancient cultures. Works of art from the collection of the State Hermitage Museum. An exhibition catalog] / ed. by M. B. Piotrovskii. St. Petersburg, Slaviia. 144 p. Pp. 47-53. (In Russ.).

Chugunov, K. V., Partsinger, G. and Nagler, A. (2017) Tsarskii kurgan skifskogo vremeni Arzhan-2 v Tuve [Arzhan II, the royal mound of the Scythian time in Tuva]. Novosibirsk, Izd-vo IAET SO RAN. 500 p. (In Russ.).

Khovalyg, R. B. (2009) K istorii vozvrashcheniia arkheologicheskoi kollektsii «Arzhaan-2» v fondy Natsional'nogo muzeia im. Aldan-Maadyr Respubliki Tyva [On the history of the return of the archaeological collection "Arzhaan-2" to the funds of the Aldan-Maadyr National Museum of the Republic of Tuva]. In: Nasledie narodov Tsentral'noi Azii $i$ sopredel'nykh territorii: izuchenie, sokhranenie i ispol'zovanie [Heritage of the peoples of Central Asia and adjacent territories: study, preservation and use]: Proceedings of an International Conference, Kyzyl, 9-10 Sep. 2009: in 2 parts / ed. by V. S. Chigzhit; comp. by U. B. Nurzat; ed. by U. P. Opei-ool. Kyzyl, Tipografiia KTsO «Anyiak». Part 2. 199 p. Pp. $149-152$. (In Russ.). 